\title{
A AEQUITAS COMO PRINCÍPIO FUNDAMENTAL DO DIREITO ROMANO CLÁSSICO: UMA INVESTIGAÇÃO HISTÓRICO-FILOSÓFICA
}

\author{
Igor Moraes Santos ${ }^{1}$
}

\section{Resumo}

O artigo tem por objetivo investigar as funções e os limites da aequitas no direito romano clássico. A partir do exame de fontes originais e de estudos jurídicos e filosóficos sobre a cultura jurídica latina, este trabalho perpassa três etapas: primeiro, tenta compreender a peculiaridade da aequitas em face da tradição grega e moderna; segundo, investiga o exercício da aequitas, a partir dos princípios auxiliares utilitas, analogia, prudentia e fides, por fim, examina os efeitos da equidade em Roma, em especial, na elaboração e aplicação do direito pelas vias do ius gentium e do ius praetorium. Assim, revela-se como a aequitas toma forma de um princípio fundamental retor do direito romano clássico, responsável por sua complexidade, riqueza e força exemplar.

Palavras-chave: aequitas; equidade; Roma; direito romano; justiça.

\section{INTRODUÇÃO}

A arraigada unidade sociocultural foi uma das principais características do mundo antigo. O homem era o cidadão, somente percebido enquanto integrante da cidade. O peso do ser unitário no interior da organização sócio-política era diminuto, podendo inclusive ser sacrificado em prol de sua preservação. Assim, figurava-se um forte contraste entre a universalidade representada pela cidade, com seus valores, tradições e normas coletivas, e a particularidade do homem-cidadão, dissolvido na realidade totalizante da polise da civitas.

Entretanto, não havia completa desconsideração das especificidades próprias do homem, embora o indivíduo se torne conceito pleno apenas na Modernidade. Com efeito, se na cultura greco-romana era inegável o peso do todo social frente ao humano unitário, existia também a percepção da necessidade de reconhecimento de algumas de suas peculiaridades, manifestadas nas variadas relações interpessoais, de modo a ser impossível tratar da ideia de justiça sem as considerar.

A lei representa a consolidação de valores inerentes à comunidade e que, portanto, devem servir como critério de medida do que corresponde a cada um na distribuição dos bens sociais. Contudo, a lei deve ser geral e impessoal para, desse modo, abarcar todos os cidadãos e os seus respectivos laços sociais. As particularidades do

\footnotetext{
${ }^{1}$ Doutorando em Direito pela Universidade Federal de Minas Gerais. E-mail: santosigormoraes@gmail.com
} 
homem concreto, se ignoradas em favor das determinações uniformes do comando legal, em vez de gerar a justiça, fim último, como pretendido, gerará injustiças. Os fatos são sempre muito mais ricos que o legislador mais sábio poderia prever e enfeixar em uma norma estática. Isso já era percebido pelos helênicos, como registra Aristóteles, com sua metodologia de observações empíricas pela qual recolhe práticas e noções difundidas na cultura. A equidade, epieikeia, surge como instrumento de mediação ou de equilibrio entre a universalidade e a particularidade, entre a lei e o fato, entre a cidade e o cidadão, uma vez que impede a injustiça concreta.

Entre os romanos, uma noção semelhante, a aequitas, ascende em meio à consolidação dos elementos formadores do direito, elevado à posição central na estrutura da vida humana, tornando-se também jurídica. Assim, o direito fornecerá em seu seio diretrizes para a obtenção do equilíbrio e, por conseguinte, para permitir a concretização do justo. Roma terá na aequitas mais do que mero instrumento acessório à lei, será ela verdadeiro princípio norteador de todo o direito e, logo, de toda a sociedade. A equidade romana permitirá ampla criação de novos institutos jurídicos, para além da gradual formação normativa costumeira, de forma prudente e proporcional às demandas da civitas e da nascente figura do sujeito de direitos, ao menos na fase clássica do direito romano,

Uma noção com tamanho peso nas raízes histórico-axiológicas do direito ocidental cumpre ser destrinchada, pois uma correta compreensão de sua formação e de seu real funcionamento pode contribuir para novas perspectivas em relação às ideias de justiça e de equidade na contemporaneidade, particularmente se considerados os rumos diversos assumidos no sistema jurídico romano-germânico. Para tanto, recorre-se neste trabalho a uma interpretação histórico-filosófica dos textos de época, auxiliada por intérpretes modernos, que perpassa três momentos: primeiramente, conecta-se a aequitas romana com a tradição grega e moderna, comparando sentidos e transformações semânticas, para então afirmar as suas peculiaridades; posteriormente, investiga-se o exercício da aequitas, apoiado em alguns princípios norteadores; por fim, examina os efeitos da equidade em Roma, em especial, na formulação de novos institutos jurídicos, segundo os contextos da cultura jurídica latina, pela via do ius gentium e do ius praetorium. Assim, espera-se revelar como a aequitas toma forma de um princípio fundamental retor do direito romano clássico.

\section{DA EPIEIKEIA A EQUIDADE MODERNA}

Como observado anteriormente, a equidade é noção que permeia a cultura greco-romana. Com efeito, a justiça é elemento basilar da vida social por definir o que cabe a cada um, regulando as relações entre cidadãos com fulcro a garantir a igualdade e, por conseguinte, a harmonia no seio da comunidade.

A percepção da justiça entre os gregos estava atrelada à moral, como uma virtude. É assim em Platão, 
para quem a justiça não era a mera conveniência do mais forte, mas alcançada quando se tinha o equilíbrio da alma, entre as partes irascível, concupiscente e racional. Da mesma forma era a justiça na cidade, configurada quando cada grupo social realizava as funções que lhe cabiam, ou seja, era realizar adequadamente aquilo que the fora definido por natureza (PLATÃO, 2001). Mas já Platão entrevera as limitações das leis humanas, reflexos imperfeitos da ideia de justiça no mundo em que vivemos².

Aristóteles desenvolverá essa questão. Para ele, a justiça é definida como uma virtude ética, isto é, um meio-termo entre os extremos do excesso e da falta, que para ser obtida depende da prática constante até se tornar um hábito, como uma segunda natureza. O Estagirita também notava a peculiaridade da justiça em comparação com as demais virtudes, em especial por seus extremos serem apenas por falta, inexistindo ação com "excesso de justiça”, mas tão somente quem é injusto por não agir justamente. Ademais, o filósofo percebeu diferentes acepções no interior da noção de justiça, como a justiça legal e a justiça particular que, em última instância, também expressam a justiça atrelada aos laços sociais, notadamente nas leis que regem a cidade, e nas relações entre cidadãos (ARISTÓTELES, EN,V, 1129a-1138b).

No contexto do pensamento aristotélico sobre a justiça, a equidade surge como instrumento indispensável de efetivação do justo legal. A lei é, caracteristicamente, genérica, uma vez que goza de pretensão de validade universal, pleiteia ser aplicável a todos os cidadãos, independentemente das vicissitudes especiais que alguns possam ter. Em razão da abstração e da uniformidade, quando aplicada em certos casos concretos da forma como seu conteúdo dispõe, a lei poderá gerar injustiças fáticas, em total inversão de seu objetivo primordial de justiça. Assim, a epieikeia foi desenvolvida como "forma de abrandar o rigor da lei", corrigir a lei, o direito (SALGADO, 2006, p. 215), tendo em vista afastar essas possíveis injustiças. Nesse ponto, Aristóteles recorre à figura da Régua de Lesbos como ilustração: enquanto as réguas tradicionais são rígidas, a régua utilizada pelos engenheiros dessa ilha grega é maleável, o que permite que se amolde às formas irregulares das pedras. É dessa forma que a equidade age. Isso faz do equitativo um justo melhor do que a simples justiça, por ser uma justiça natural e, por ser mais perfeita, é superior à justiça política, regida pela lei humana (ARISTÓTELES, EN, 1137b; CARMIGNANI, 2009, p. 116).

Tais noções acerca da relação entre justiça, igualdade e equidade ficaram assentadas na cultura grega, difundindo-se no senso comum, inobstante interpretações diferentes dadas por outras correntes filosóficas ao longo do período helenístico. Nesse sentido, cabe destacar o papel do estoicismo.

\footnotetext{
${ }^{2}$ PLATÃO, O político, 294a-b: "É que a lei jamais seria capaz de estabelecer, ao mesmo tempo, o melhor e o mais justo para todos, de modo a ordenar as prescrições mais convenientes. A diversidade que há entre os homens e as ações, e por assim dizer, a permanente instabilidade das coisas humanas, não admite em nenhuma arte, e em assunto algum, um absoluto que valha para todos os casos e para todos os tempos."
} 
Em suas formulações originais, ainda em solo ático, com Zenão e Crisipo, no século III a.C., os estoicos apregoavam uma rígida concepção de justiça, definida como dar a cada um o que the é devido "segundo o lógos, medida abstrata, invariável e impessoal" (MATOS, 2009, p. 334), portanto, absoluta e imutável, garantida pela lei natural, razão ordenadora do kosmos e, assim, independente da lei positiva humana. Desse modo, não havia margem para se aceitar a flexibilização das sanções, enfim, a necessidade da própria equidade, pois, diversamente de Aristóteles, para a Stoá, o conceito de justiça não se amolda às plurais manifestações concretas de formas de governo e grupos sociais (MATOS, 2009, p. 335).

A partir dos contatos dos estoicos gregos com a cultura romana, marcada pelo apelo prático no plano social, político e jurídico, especialmente nos séculos II e I a.C., novas reflexões resultarão em formulações um tanto diversas sobre a justiça. De fato, agora o Direito passa a ser compreendido como reflexo da racionalidade cósmica e, apesar de não ser perfeito, não deve ser simplesmente negado, mas aprimorado. Matos recorda em Cícero a ilustração da transformação do caráter da justiça estoica em Roma por meio do registro de uma discussão entre Antípatro de Tarso e seu mestre Diógenes da Babilônia sobre o possível conflito entre a utilidade e a honestidade (CÍCERO, De off., III, 50-57). As posições dos filósofos giram em torno de dois conceitos diferentes de justiça, o do primeiro é tipicamente grego, sendo lei natural geral e totalizante, enquanto o do segundo é influenciado por ares romanos, diferenciando o justo legal (iustum) do justo moral (aequum):

A justiça é entendida por Diógenes como obrigação de ordem estritamente legal que, todavia, pode ser complementada ou corrigida pela obrigação de natureza moral fundada na aequitas. Para Diógenes, a lei civil é em si mesma justa. Entretanto, ela não se configura como padrão único de justiça, dado que as normas jurídico-positivas não esgotam o sentido da recta ratio, a ser concretizada em sua inteireza mediante o constante apelo à moralidade extralegal do equitativo e do razoável. Eis uma concepção bem romana de justiça. (MATOS, 2009, p. 337-338)

Será Panécio o responsável por, finalmente, elaborar um conceito de justiça a unir os preceitos estoicos com os elementos fundamentais da sociedade romana. Para ele, a justiça tem por cerne a equidade 3 , de modo que dependem ambas uma da outra. A aequitas é, portanto, incluída no seio da iustitia, o que não implica poder ser empregada como pretexto para o desrespeito da ordem jurídica posta ou observância cega à letra da lei, pois a justiça está no sentido, e não na literalidade do texto legal (MATOS, 2009, p. 338).

Assim, resta evidenciada a influência da cultura romana na filosofia do período helenístico, mas cumpre analisar o caminho inverso. Para Schulz, a partir do fim da Segunda Guerra Púnica, a jurisprudência romana entrou em uma nova fase marcada pelo helenismo, período este oportuno, considerando que, por um lado, a iurisprudentia estava suficientemente desenvolvida para não ser dominada pelas influências gregas, e, por outro,

\footnotetext{
${ }^{3}$ Cf. CÍCERO, De off., I 64, referência a partir do entendimento de que a maior parte do Livro I da obra ciceroniana é inspirada no tratado de Panécio sobre a moral.
} 
era ainda jovem e dinâmica, passível de ser estimulada pelo pensamento ático (SCHULZ, 1946, p. 38-39). De fato, durante certo tempo, alijados do restrito círculo dos iurisconsulti, os oradores adquiriram a arte da retórica judiciária e política de professores e manuais estrangeiros, de modo a reproduzir contrastes próprios da eloquência da Hélade, como a oposição entre direito e equidade (SCHULZ, 1946, p. 71-72). Ao mesmo tempo, tais contradições foram nutridas por filósofos e retores gregos residentes em Roma ${ }^{4}$. As ideias estoicas, por exemplo, foram bem recebidas no círculo de políticos e juristas liderado por Cipião, que acolheu Panécio e proporcionou a difusão delas pela aristocracia e entre os jurisconsultos (CORRÊA, 1950, p. 18-21; POHLENZ, 1967, p. 389 et seq). Corrêa (1950, p. 45-55), na esteira de Cuq, resgata brevemente a evolução da jurisprudência romana da casuística de seus fundadores, como P. Múcio, Bruto e Manílio, até o período clássico, com seus impulsos de sistematização, estes associados a traços estoicos, como entre cultores do porte de Quinto Múcio Cévola e Sérvio Suplício. Krueger (1894, p. 61), por sua vez, chega ao ponto de defender que os jurisconsultos "pegaram emprestados dos filósofos gregos o método científico aplicável em geral a todos os ramos dos conhecimentos humanos". Em suma, teria se constituído uma unidade orgânica de elementos teóricos gregos e práticos romanos, indispensáveis para a formação do direito de Roma.

Por isso, seja por um fundo ético comum (MONCADA, 1923, p. 60, nota 1), seja pelos influxos diretos permitidos pelos contatos interculturais, a equidade, como aequitas, preservou traços helênicos fundamentais, a exemplo da pretensão de evitar a injustiça em relação aos fatos concretos e de garantir a igualdade entre os cidadãos. De fato, relata Falcón y Tella que a primeira relação de parentesco etimológico identificável é entre aequitas e o grego eikós, que significa conveniente, correspondente à verdade, o exato, o justo, enquanto epieikeia expressa a noção de conveniência. Por outro lado, aequitas remete ao sânscrito aika ou aikya (o uno) e aikatuan (unidade, semelhança), portanto, efetivamente aludindo às ideias de igualdade, equilíbrio, proporção (FALCÓN Y TELLA, 2005, p. 49). Segundo Bonfante, aequitas tem origem no radical aika, dele derivando, na língua latina, o substantivo aequor (superfície plana, planície), o adjetivo aequus (plano liso, sem altos nem baixos, igual, justo, imparcial) e o verbo aequo (aplainar, tornar igual, nivelar, igualar) (BONFANTE, 1900, p. 116; 1951, p. 7-8; FARIA, 1962, p. 44). De todo modo, como assinala Salgado, em Roma, a justiça torna-se ideia propriamente de Direito e, dessa forma, a aequitas passa a ser um "modo de fazer justiça, de estabelecer o equilíbrio entre a consequência e o ato e a consequência jurídica do ato" (SALGADO, 2006, p. 215-216). O encontro de elementos culturais romanos e gregos produz um resultado original, o que repercute também na ideia de equidade.

O principal aspecto diferenciador entre a epieikeia, a equidade grega no sentido aristotélico, e a aequitas, a equidade romana é, segundo Salgado, a atuação não na lei diretamente, mas no fato. É o caso concreto, com suas

\footnotetext{
${ }^{4}$ Em sentido contrário, para Arangio-Ruiz (1974, p. 340), o estoicismo e o epicurismo não influenciaram profundamente a
} 
peculiaridades, o alvo de uma ação corretora que lhe coloca em conformidade com o direito, e não este que é alterado, adaptado ou estendido para lhe abarcar. $\mathrm{O}$ enfoque está nas necessidades humanas, fáticas, e como elas deixam de ser satisfeitas pela lei, salvo com o sacrifício do particular. Nas palavras de Salgado (2006, p. 215-216), "é isso mesmo que faz o direito: corrige o fato, impõe-lhe racionalidade pela ponderação da aequitaš. Correção do fato na responsum, considerando que, no sistema processual de ações das leis, com seu rígido formalismo, deverse-ia ter a aceitação da demanda com a aplicação de uma actio correspondente a um direito lesado, sendo incabível ao pleiteante intentar a reforma da lei, expressão de valores consolidados pela comunidade, reiterados no tempo na forma de costumes, lastreados na tradição.

A dicotomia em questão gera uma oposição interna entre o direito como lei positiva e o direito como ideal ético, cujos termos romanos são expressos na contraposição entre ius e aequitas ou entre bonum e aequum (BONFANTE, 1900, p. 116). Nesse sentido, a equidade é concebida em contraste com o ius civile, ou como exceção a ele, entendido como ius strictum. Para Falcón y Tella (2005, p. 51-52), toda a história do direito romano pode ser sintetizada como um constante esforço para superar o ius strictum com o ius aequum, fazendo triunfar a equidade do ius gentium frente às concepções formalistas do direito civil antigo, por meio do ius praetorium ou ius honorarium, e do trabalho dos jurisconsultos romanos, como veremos com detalhes adiante.

Para Krueger (1894, p. 165 et seq), os jurisconsultos classificam a aequitas em oposição ao ius civile, como Cícero, que absorve dos prudentes de seu tempo o modo de aplicar a equidade, expressa em algumas obras, como Brutus (143-144) e De oratore (173). Isso porque ela proporciona uma via alternativa ao direito civil, por exemplo, ao permitir o reconhecimento pelo pretor da validade de contratos não solenes. Contudo, em outras passagens ${ }^{5}$, Cícero trata a aequitas não em contraste com o ius civile, mas como sua aplicação mais exata e justa, em oposição sim ao respeito estrito à letra da lei. Disso resulta, como assinala Schulz, a inexistência de contraposição real entre ius e aequitas, antítese que pertence à retórica aristotélica, não à jurisprudência romana. Com efeito, "aequitas, se aceita pelo direito, éo direito e não pode mais ser contraposta ao ius" (SCHULZ, 1946, p. 240). O direito é penetrado pela aequitas e, assim, como o ars boni et aequi de Celso, tem nela a sua substância, enfim, é um direito justo (MOREIRA ALVES, 2000, p. 77-79). A aequitas não é para os jurisconsultos romanos um princípio único, mas representa o progresso do ius. Sua ação é desempenhada no domínio do ius, que passa então a estar compreendido na noção de aequitas, em suma, como ars boni et aequi (KRUEGER, 1894, p. 168).

A presença da aequitas não representa aversão à teoria pelos romanos. Eles já conseguiam realizar um vigoroso exercício de abstração, consistindo na criação de normas dirigidas a casos previamente concebidos,

elaboração das categorias jurídicas entre os romanos.

${ }^{5}$ CÍCERO. Mur. 27: "Em suma, se considerarmos o direito civil na sua completude, deixaram de lado a verdadeira equidade e se ativeram pura e simplesmente à letra da lei”. 
possíveis de ocorrerem na realidade concreta, mas sem descurar das nuances próprias dessa mesma realidade, rica em variáveis, imprevisíveis. Assim, formavam um equilíbrio entre o abstrato e o concreto, entre o particular e o universal, o que era garantido precisamente pela aequitas (CARMIGNANI, 2009, p. 128).

Sobressai-se, desse modo, um contraste entre gregos e romanos. Os helenos fizeram uso da razão com olhos voltados predominantemente para a reflexão teórica e, quando estendida para a filosofia prática, não se ocuparam em criar mecanismos efetivos de aplicação da teoria na realidade, posto que o agir era problema do interior humano (o justo restrito ao plano moral). Entre os romanos, por sua vez, a razão passou a servir de orientação para a vida prática (PINTO COELHO, 2009, p. 50-52). Outrossim, se os gregos já abstraíam no processo de elaboração de suas leis, tal operação não gozava da universalidade que os romanos alcançaram. Por um lado, a Lei das XII Tábuas representou um impressionante esforço abstrativo, mas é nítido como nela se evitou tecer definições, assim como em todo o direito arcaico. Por outro, a partir do fim da República, a intensificação da filosofia helênica e o desenvolvimento da jurisprudência expandiram a prática de categorizações, ao passo que cotejadas com a ponderação do concreto (SCHULZ, 1936, p. 40-41).

Logo, para os romanos, a busca do universal, para além da teoria e da ética, chega ao direito, que não se faz a partir da contingência dos fatos, mas pela unidade destes, principalmente na forma de lei escrita: "A categoria da universalidade é, pois, um resultado natural da necessidade de logicização ou racionalização do direito romano, que é fruto de uma mesma cultura e uma mesma índole étnica, a encontrar na diversidade aparente dos dois povos a unidade da razão" (SALGADO, 2006, p. 44). A lei é posta em nome de toda a sociedade e se dirige a todos, manifestando-se a universalidade, formalmente, na bilateralidade da relação, e materialmente, na exigibilidade, movimentos que resultam na irresistibilidade do direito. Com efeito,

O direito é irresistível, com pretensão de validade absoluta (Stammler), por força dessa movimentação dialética da universalidade abstrata diante da particularidade da relação social, de que resulta a bilateralidade, e da universalidade material ou axiológica que, diante da particularidade da relação social, se mostra como exigibilidade. Dessa superação dialética entre o universal bilateral e exigível e a particularidade da relação social é que surge o direito como ordenação irresistível. (SALGADO, 2006, p. 86)

$\mathrm{O}$ afastamento da morosidade da formação normativa consuetudinária, além da segurança jurídica, é um dos motivos para a ascensão da lei escrita, mas também ela era insuficiente com sua excessiva abstração, ensejando, assim, a emergência do ius honorarium que, pela aequitas, empenha-se por balancear essas dimensões (PINTO COELHO, 2009, p. 123).

É patente como a consciência jurídica romana era ciente da complexidade da realidade e das limitações humanas em compreender a pluralidade dos fatos que nela se desenrolam. O homem integra o kosmos, uma totalidade ordenada, relação esta inelutável. Pela perspectiva estoica, resta a ele somente aceitar essa condição, verdadeiro ato de liberdade, harmonizando-se com o universo pela apreensão da ratio naturalis, à qual a razão 
humana é equiparada (CÍCERO, De leg. I 6; De rep. III 17). Por isso, as leis humanas devem estar em conformidade com as leis naturais, reflexos destas. A identificação da razão humana com a razão divina abre a possibilidade ao homem de elaborar leis tão perfeitas quanto a divindade. É uma razão objetivada, embora ainda abstrata, como inserta nas coisas do mundo, a permitir o avançar do processo de "desalienação da consciência jurídica” (SALGADO, 2001, p. 10). Nesse sentido, se o ius civile não apresentava uma solução, dever-se-ia recorrer ao ius naturale para tentar extrair alguma resposta (SALGADO, 2006, p. 217). Há uma noção de justiça natural imanente que, contrastada com a justiça humana, poderá mostrar seus defeitos e imprecisões, permitindo ao homem aprimorá-la.

Nessa linha, Arangio-Ruiz (1952, p. 32, nota 15) observa que a aequitas e o adjetivo aequus foram frequentemente utilizados para valorar a correspondência das instituições ao sentimento jurídico prevalecente, que se referia à naturalis ratio, e daí decorre a menção de uma aequitas naturalis. Numerosos são os exemplos em que os jurisconsultos tratam dessa aequitas naturalis. Gaio descreve como, "movido o Procônsul pela equidade natural promete a posse dos bens a todos os cognados" (D. 38, 8, 2), ou ainda, "porque nada é tão conforme à equidade natural como que se tenha por válida a vontade do dono que quer transferir a outro uma coisa sua” (D. 41, 1, 9, \$3). Também Paulo menciona, sobre a exceção de dolo mau e de medo, como "o pretor propôs esta exceção, para que nada o aproveite, contra a equidade natural, seu próprio dolo por ocasião do direito civil" (D. 44, $4,1, \$ 1)$ e, acerca do postliminium, como "isto se introduziu por equidade natural, para que ele, injustamente detido por estrangeiros, recobrasse seu primitivo direito logo que houvesse voltado a seus próprios confins" (D. $49,15,19 \mathrm{pr})^{6}$.

Cícero, nos Topica, distingue a aequitas naturalis da aequitas civilis, a equidade lastreada na ordem natural e a equidade oriunda do próprio homem:

Quando se discute sobre o "équo" o o "iníquo", recolhem-se as passagens que dizem respeito à equidade. Elas são distinguidas em duas, segundo a natureza ou as instituições. A natureza tem duas partes: a atribuição a cada um o seu e o direito de punir a culpa. Mas a instituição da equidade é tripla: uma parte baseia-se na lei, outra no acordo, uma terceira é estabelecida na antiguidade dos costumes. [E também a equidade é dita tripla: uma pertence aos deuses superiores, outra aos espíritos dos mortos, a terceira aos homens. A primeira é denominada piedade, a segunda sacralidade, a terceira justiça ou equidade.] (CÍCERO, Top, 90 ${ }^{7}$

Bretone (1998, p. 248-249) enfatiza que a distinção não é rigorosa na mente do intérprete, uma vez que as relações são muito próximas:

\footnotetext{
${ }^{6}$ As referências ao Digesta ao longo do texto são de JUSTINIANO, 1889; 1892; e 1897.

${ }^{7}$ Tradução nossa cotejada com a inglesa. No original: "Cum autem de aequo et iniquo disseritur, equitatis loci colligentur. $H i$ cernuntur bipertito, et natura et instituto. Natura partis habet duas, tributionem sui cuique et ulciscendi ius. Institutio autem aequitatis tripertita est: una pars legitima est, altera conventis, tertia moris vetustate firmata. [Atque etiam aequitas tripertita dicitur esse: una ad superos deos, altera ad manes, tertia ad homines pertinere. Prima pietas, secunda sanctitas, tertia iustitia aut aequitas nominatur.]"
} 
A aequitas naturalis, por nós chamada um tanto arbitrariamente em causa, não teria aqui outra função que a de fundar, a partir do exterior, um limite razoável à aplicação de um determinado regime jurídico. Mas a aequitas naturalis, contrapondo-se à aequitas civilis, pode atuar de maneira mais radical: ela pode consentir um olhar crítico sobre o sistema, e dar lugar a um novo preceito jurídico, em contraste com sua lógica interna. Não é um caminho fácil. O jurista que tencione percorrê-lo, sabe ter de atravessar um limite, dentro do qual habitualmente se desenvolve o seu trabalho, proclamar-se intérprete do "justo" segundo uma sabedoria prática que está para além da técnica. Todavia, entre os dois momentos, um técnico e outro que diríamos filosófico, não há para ele nenhuma divisão: eles implicam-se um ao outro. Definitivamente, a mesma técnica jurídica - que a Cícero, mesmo ambiguamente, parecia necessária mas "ténue" de um ponto de vista teórico - descobre-se ancorada a um universo de valores que só se manifesta em momentos particulares.

A antítese entre aequitas civilis e aequitas naturalis era um topos lógico-retórico, no qual encontravam apoio persuasões éticas largamente partilhadas.

O homem, por mais destacado que possa ser em relação aos demais seres, estará em constante tentativa de compreender as leis que regem esta totalidade cósmica e, assim, bem elaborar as leis próprias a regerem a sua organização social e as suas relações com os outros cidadãos. De qualquer modo, ao consolidar essas leis, jamais conseguirá incluir nelas toda a diversidade do mundo. Este é um dos motivos pelos quais os latinos evitarão dar respostas prontas e imutáveis aos problemas e preferirão frequentemente solucionar as demandas conforme surjam e segundo os traços próprios que carreguem. E, para tanto, deverão ter um instrumento adequado para reconhecer o particular e inseri-lo harmonicamente no universal. Não basta simples senso de justiça ou vago “sentimento de direito", tanto porque a epieikeia aristotélica era já um referencial firme (BRETONE, 1998, p. 247), mas a concordância das normas jurídicas com o "senso universal de justiça”, sem a qual jamais alcançaria "o direito romano a universalidade a que atingiu" (LAGES, 1949, p. 36). Para tanto, a lei tem o rigor decorrente de sua abstração e, com isso, evita-se a injustiça pela aplicação do próprio direito (SALGADO, 2006, p. 214), pois, como registrou Cícero, summum ius summa iniuria (CÍCERO, De off., I 33). Em outras ocasiões, a lei até permanecerá inalterada e caminhos adjacentes serão suficientes para harmonizá-la, como a inserção de uma nova lei ao lado daquela, de forma a dar respostas a situações até então alijadas da órbita jurídica pelos diplomas vigentes.

É em virtude disso a dificuldade de se definir, em termos contemporâneos, a aequitas. Hoje relegada a um segundo plano no ordenamento jurídico dos países de filiação romano-germânica, a equidade moderna é mero recurso, subsidiário, ao qual pode o magistrado se valer para a solução do caso, quando outros instrumentos falharem ${ }^{8}$. Embora persista um tanto transformado no sistema de common law, a doutrina civilista em larga medida rejeita a equidade por sua suposta discricionariedade exagerada, temerária em um contexto no qual a segurança jurídica é pressuposto inarredável.

\footnotetext{
${ }^{8} \mathrm{Na}$ ordem jurídica brasileira contemporânea, a equidade encontra-se presente no Código de Processo Civil e no Código Tributário Nacional, em qualquer caso, também em posição desprestigiada frente a outros mecanismos jurídicos.
} 
Para Perozzi (1928, p. 111-113), os modernos consideram a equidade a perfeita correspondência da decisão jurídica a todas as circunstâncias do caso. Em contrapartida, a aequitas seria uma noção de justiça ideal, como "princípio em parte justificador, em parte inovador a respeito do direito existente, mas que se traduz sempre em preceitos de direito" (tradução nossa). Para Bonfante (1900, p. 116-120) é um erro associar a aequitas à nossa equidade ou, ainda, ao termo alemão Billigkeit. $\mathrm{O}$ sentido moderno mais preciso seria justiça. Como resume o autor, "a equidade moderna é um conceito individual, a aequitas romana é a ideia social da justiça". Assim, a aequitas era palavra a representar o princípio informador do direito de estabelecer quais as condições e os limites ao fazer do particular, o que ocorre tendo em conta as razões de cada igual e a relação travada com os outros consorciados, utilizada, em suma, "para indicar o direito sob o aspecto intrínseco e final, isto é, em seu escopo e essência" (BONFANTE, 1951, p. 7-8) (tradução nossa).

A partir da ascensão do Cristianismo, aequitas e aequus adquiriram o sentido de benignidade, indulgência, em geral com relação às circunstâncias do caso apresentado ao juiz, como se verifica nas constituições de Justiniano e nos textos dos jurisconsultos interpolados pelos compiladores. Para Bonfante (1951, p. 7-8), esse sentido das novas fontes será a influência prevalecente para a equidade moderna, e por isso afirma que:

A aequitas não corresponde à nossa equidade, não representa, pois, uma temperança aportada à lei em um caso particular, por razões de humanidade e de doçura, mas sim corresponde substancialmente ao nosso conceito de justiça e, portanto, a aequitas pode inclusive sugerir um tratamento mais duro e uma pena mais severa, se isso é conforme à justiça. (BONFANTE, 1944, p. 478) (tradução nossa)

Delimitado o sentido de aequitas, percebe-se sua presença tanto nos momentos de elaboração quanto nos de aplicação da lei. Com isso, há agora a necessidade de conhecer seus princípios auxiliadores e, na sequência, seu funcionamento no cotidiano forense romano.

\section{PRINCÍPIOS AUXILIARES DA AEQUITAS: UTILITAS, ANALOGIA, PRUDENTIA}

\section{E FIDES}

A aequitasé, concomitantemente, instrumento poderoso de desenvolvimento jurídico, a acompanhar as conquistas e os desafios sociais, e mecanismo possibilitador de transformações arbitrárias e parciais do direito. Este é um argumento corriqueiro na atualidade nos ordenamentos de filiação romano-germânica, em que a flexibilidade proporcionada pela equidade moderna é vista com temor de ferimento aos princípios da segurança jurídica e da própria igualdade. Os romanos estiveram atentos a esses eventuais problemas e, assim, ao lado da aequitas, tinham outras noções importantes que auxiliavam a elaboração e aplicação do direito, de modo a 
produzir um resultado idôneo e efetivo. São elas a utilitas, a analogia, a prudentia a a fides ${ }^{9}$.

Utilitas é utilidade, ter em vista a concretização de uma ordem social justa. O termo deriva de utor, verbo que significa usar, servir-se, empregar, relacionar-se, ter à disposição (FARIA, 1962, p. 1040), enfim, ter vantagem, seja abstrata ou concreta (MASTINO, 2013, p. 6). Afirmou-se inicialmente as relações entre o homem, cidadão e sujeito de direitos, e a cidade, o conjunto de cidadãos, valores, normas e instituições. Eis aqui uma face de expressão jurídica dessa conexão: a satisfação de um interesse individual não pode ser tal que provoque ônus insuportáveis à comunidade.

A utilitas dirige-se à realização de uma "ordem social pela eficácia do direito", como ordem jurídica, por isso, de justiça (SALGADO, 2006, p. 250). Assim, como lembra Salgado, mesmo um direito especial pode ser reconhecido em face da sociedade, quando racionalmente justificável, conforme preleciona Paulo (D. 1, 3, 16), para quem "direito singular é aquele que, contra o teor da razão, por causa de alguma utilidade, foi introduzido com a autoridade dos que o estabelecem" ${ }^{10}$. Em outros termos, a atribuição de um direito, no plano social e individual, deve se dar de forma justa, equitativa, quer dizer, em conformidade com a aequitas. O que Santo Tomás de Aquino chamará de bem comum é construído, dialeticamente, como o bem da sociedade e, ao mesmo tempo, o bem de cada um dos membros particulares (SALGADO, 2006, p. 251), de modo que, sempre, cidadão particular e comunidade sejam considerados no momento da criação e da aplicação do direito. Nesse sentido, nas palavras de Modestino (D. 1, 3, 25), "nenhuma razão de direito ou benignidade da equidade permite que, aquilo que foi introduzido para o bem-estar do homem seja interpretado de modo excessivamente severo contra o bemestar dos mesmos homens" ${ }^{11}$, passagem que, como salienta Salgado (2006, p. 251), trata o "homem" tanto como comunidade (hominum) quanto como particulares, pessoas (ipsorum).

Preocupar-se com o que é útil é próprio do direito, dispensando o que é irrelevante social e juridicamente. Portanto, a utilitas "exclui o inútil e o nocivo e capta o que é vantajoso e conveniente para a sociedade", quer dizer, precisamente, "o justo, porque só por meio dele se alcança a paz social ou a conveniência harmônica dos indivíduos" (SALGADO, 2006, p. 251).Juridicamente, o sentido de utilitasé:

É utilidade social da norma, e isso é o que se denominou bem comum e, como a solução de conflito de interesses exige sempre a estrutura da justiça formal, sem o que não há direito para o romano, utilitas é a própria justiça na aplicação, em que sempre se recorre à aequitas, que não é o arbitrio nem o sentimento do "bom juiz", mas o equilibrio assinalado pela razão prudencial ponderativa para a solução do conflito. (SALGADO, 2006, p. 251)

\footnotetext{
${ }^{9}$ Parte desta seção foi desenvolvida em nosso SANTOS, 2018.

${ }^{10}$. Cf. JUSTINIANO, 1889, p. 210 (tradução nossa cotejada com a espanhola). No original: "Ius singulare est, quod contra tenorem rationis propter aliquam utilitatem auctoritate constituentium introductum est."

${ }^{11}$ Cf. JUSTINIANO, 1889, p. 211. (Tradução nossa cotejada com a espanhola). No original: "Nulla iuris ratio aut aequitatis benignitas patitur; ut quae salubriter pro utilitate hominum introducuntur, ea nos duriore interpretatione contra ipsorum commodum producamus ad severitatem." (Observar que o termo benignitas pode ser uma interpolação do período justinianeu.)
} 
Contudo, essa conotação jurídica de utilitas, segundo Mastino (2003, p. 5), somente ocorreu com Cícero, com quem é delineado um conceito "que caracteriza o ius e a realização da iustitia: é um conceito pragmático, que exerce a sua função de iure condendo e de iure condito, conferindo ao direito aquela função prática que lhe justifica a essência”.

Ainda que se considere precisa a defesa de alguns autores acerca da existência de uma diferença entre as noções de utilitas communis e utilitas publica (MASTINO, 2003, p. 8), importa observar, de qualquer modo, como a ideia de utilidade reflete um olhar social, análise de circunstâncias vantajosas para a sociedade, para além das particularidades do sujeito singular, embora também consideradas. À vista disso, a res publica é a "reunião que tem seu fundamento no consentimento jurídico e na utilidade comum" (coetus multitudinis iuris consensu et utilitatis communione sociatus) (CÍCERO, De rep., I, 25) e justamente em seu seio nasce o direito pretoriano, "aquele que os pretores introduziram para ajudar ou suprir ou corrigir o direito civil, por causa da utilidade pública, e o qual é também chamado honorário, assim denominado em honra dos pretores" (PAPINIANO. D. 1, 1, 7, $\$ 1)^{12}$.

Ademais, a utilitas não é um conceito autônomo, mas se reconduz à justiça. Atinge sua função própria ao se corresponder com o direito natural e com os outros princípios que dele derivam (MASTINO, 2003, p. 9). Cícero afirma que a única justiça é por natureza, enquanto aquela que "se funda na utilidade encontra-se aniquilada pela própria utilidade” (CÍCERO, De leg., I 42) ${ }^{13}$, ou ainda, que se a justiça não procede da natureza, referindo-se somente à utilidade, "não é possível encontrar um homem de bem" (CÍCERO, De fin., II 59), quer dizer, um homem justo.

Nessa linha, a utilitas relaciona-se com outros princípios derivados da lei natural, entre os quais sobretudo a honestasinfluencia os vínculos travados com a aequitas. Novamente, Cícero afirma que o útil está "no mérito, no decoro e na honestidade" (De off, III 101) e que "não pode existir utilidade que seja contrária à honestidade" (De off., III 119). Para Mastino, há um influxo recíproco entre utilitas e honestas, mormente no "nível interpretativo de um determinado ato ou fato jurídico", de forma que "a utilitas, temperada pela aequitas e limitada pelo honestum, concorre para a realização da iustitia” (MASTINO, 2003, p. 12). Destarte, a aequitas nunca pode desvincular-se do útil, pois "tudo o que é justo e equitativo é igualmente honesto" (CÍCERO, De fin., III 71). Como sintetiza Salgado:

(...) a utilitas está sempre em acordo com a aequitas, isto é, com a justiça concreta, para a pessoa; não são vistas separadamente, mas no conjunto, vale dizer, a utilitas tem a função de,

\footnotetext{
${ }^{12}$ Cf. JUSTINIANO, 1889, p. 198-199. No original: "Ius praetorium est, quod praetores introduxerunt adiuvandi vel supplendi vel corrigendi iuris civilis gratia propter utilitatem publicam quod et honorarium dicitur ad honorem praetorum sic nominatur".

${ }^{13}$ Tradução nossa cotejada com a espanhola. No original: "Ita fit ut nulla sit omnino iustitia, si neque natura est, ea <que> quae propter utilitatem constituitur utilitate illa convellitur, utque si natura confirmatura ius non erit, <virtutes omnes> tollantur".
} 
em última instância, realizar a justiça, com a política de realizar o direito. Essa conjugação da utilitas e da aequitas é o próprio bem comum, definido como ordem social justa, que está a nortear a aplicação. (SALGADO, 2006, p. 250-251)

Outra dimensão importante é a analogia, a saber, a aplicação de uma mesma norma a um fato que, embora não previsto nela, apresenta elementos essenciais semelhantes àqueles da hipótese nela fixada, tem a mesma ratio essendi. Assim, a partir de comparações, conclui-se que, embora o legislador não tenha abarcado determinado fato ou circunstância fática na lei, teria feito se tivesse pensado no momento da elaboração.

Em Aristóteles, a analogia é definida como argumento a partir de um paradigma, exemplo, que conduz a uma certeza a partir de casos semelhantes, que têm partes que se relacionam (Anal. pr., II, 24, 68b-69a). Para Salgado (2006, p. 224), trata-se de conceito matemático, uma igualdade de relações, em que a igualdade é de proporção. Toma-se como modelo um fato com certas características e, depois, outro fato, no qual se constata que possui certas características que pertencem também ao outro. Esta comunhão pode ser de elementos acidentais ou essenciais, mas, como a analogia tem por resultado uma conclusão provável, a probabilidade de certeza será maior se forem comuns notas essenciais e em maior quantidade. Assim, o objetivo é encontrar uma correlação válida a partir de um fundamento comum, "a ratio do predicado que se atribui a um e outro analogado, existente no primeiro" (SALGADO, 2006, p. 224-225).

Os romanos firmaram os pilares da analogia em sentido jurídico. Embora ainda difusamente, estavam cientes de como o raciocínio segundo as semelhanças de fatos diversos podia ser útil para a realização da justiça em um contexto no qual se notava, cada vez mais, as insuficiências próprias da lei. Outrossim, vale destacar que esse mesmo exercício estava, de certo modo, difundido no cotidiano de Roma, uma vez que os exempla dos antepassados, do mos maiorum, da tradição, serviam de orientação para o agir do homem romano no momento presente. Assim, desde os tempos imemoriais, buscavam no passado os modelos para inspirar as ações atuais, o que consistia, claramente, em atividade analógica em sentido amplo.

Ulpiano (D. I, 3, 13), citando Pédio, defende que, no cerne da analogia empregada pelo jurisconsulto ou magistrado, está a já discutida utilitas: "sempre que pela lei se introduziu uma ou outra disposição, é boa ocasião para que, ou pela interpretação, ou certamente pela jurisdição, se supram as demais que tendem à mesma utilidade" ${ }^{14}$. Para Juliano, as leis e os senatusconsultos não podem ser escritos de modo a compreender todos os casos que somente ocorrem ocasionalmente, bastando "que contenham os que ordinariamente acontecem" (D. I, $3,10)^{15}$, mas, estando "manifesto seu sentido, deve aquele que exerce a jurisdição proceder por semelhança [ad

\footnotetext{
${ }^{14}$ Cf. JUSTINIANO, 1889, p. 210. No original: "Nam, ut ait Pedius, quoties lege aliquid unum vel alterum introductum est, bona occasio est, cetera, quae tendunt ad eandem utilitatem, vel interpretatione, vel certe iurisdictione suppleri."

${ }^{15}$ Cf. JUSTINIANO, 1889, p. 210. No original: "Neque leges, neque senatusconsulta ita scribi possunt, ut omnes casus, qui quandoque inciderint, comprehendantur, sed sufficit et ea, quae plerumque accidunt, contineri."
} 
similia], e deste modo, dizer o direito" (D. I, 3, 12) ${ }^{16}$. Ando (2015, p. 116) ressalta o uso também de termos como vicinuse proximus (D. 1,3,32pr). Destaca-se, ainda, o recurso analógico ao passado, mais precisamente ao direito usado antes pela cidade em casos semelhantes ( quo iure civitas retro in eiusmodi casibus usa fuisset) (PAULO, D. I, 3, 37). E, mais uma vez, Cícero sintetiza magistralmente como a analogia é essencial para a aequitas: "Prevaleça a equidade, que requer diretos iguais para casos iguais" (Valeat aequitas quae paribus in causis paria iura desiderat) (CÍCERO, Top, 23). Com efeito, suprir lacunas (iurisdicione suppleri) ao agir por semelhança (ad similia procedere) tem como finalidade proporcionar o reconhecimento e a efetivação dos mesmos direitos para fatos cuja ratio é igual ( paribus in causis paria iura desiderat), no que consiste, em essência, o proceder da aequitas.

O intérprete pode buscar essa ratio na própria regra jurídica, quando expressa, ou ainda, procurar por princípios imanentes no ordenamento, se não manifestos, o que caracteriza, respectivamente, a analogia legis e a analogia iuris (SALGADO, 2006, p. 235), conquanto esses termos somente tenham assumido os mencionados sentidos a partir do século XVIII (RODRÍGUEZ-GARCÍA, 1987, p. 619) ${ }^{17}$. Pela primeira forma, a analogia é um processo de extensão da lei, quer dizer, não há atuação fora dela, mas o alargamento de seus limites, consoante a identidade entre a ratio da norma e do fato, o que garante a sua objetividade frente a outros processos de integração do direito e, assim, a sua preferência (SALGADO, 2006, p. 231). Nesta, como ainda mais ostensivamente na segunda forma, a analogia tem revelada a sua crucial dimensão axiológica, como mecanismo de satisfação da exigência do valor igualdade, núcleo da justiça, como igualdade na ou perante a lei, em suma, como "vetor axiológico da aplicação" do direito (SALGADO, 2006, p. 234). Para além da dimensão axiológica, a analogia também uma dimensão lógica, operativa, que se articula dialeticamente com aquela para resultar na unidade da solução. Esse caráter lógico, como ressalta Salgado, é nítido na citada passagem de Juliano, visto que, "a partir de semelhanças entre um fato regulado em lei e outra a ela externo (não regulado por ela), se identifica nesse último a mesma razão (ou fundamento) pela qual a prescrição ou consequência jurídica foi atribuída ao fato pela lei", devendo-lhe ser estendida (SALGADO, 2006, p. 239). E, assim, além da exigência axiológica (necessidade de igualdade jurídica, para as mesmas situações de fato, as mesmas soluções jurídicas), segundo Salgado (2006, p. 235-236), a analogia surge no direito por exigência social (a lei não pode prever todas as situações de fato a serem reguladas) e por exigência técnica (os conceitos das leis não alcançam todos os fatos, que se enriquecem, não devendo ser esticados por interpretação imprópria ou inadequada; é técnica de decisão para suprir lacunas). Essas necessidades já estavam presentes na experiência jurídica romana, como exemplificado na criação das actiones

\footnotetext{
${ }^{16}$ Cf. JUSTINIANO, 1889, p. 210. No original: "Non possunt omnes articuli singulatim aut legibus, aut senatusconsultis comprehendi; sed quum in aliqua causa sententia eorum manifesta est, is, qui iurisdictioni praeest, ad similia procedere atque ita ius dicere debet."

${ }^{17}$ Sobre a história da analogia jurídica na Modernidade, ver BOBBIO, 1938.
} 
ficticiae, extensão de ações previstas no ius civile pelos pretores peregrinos aos estrangeiros, como se estes fossem (fingitur) cidadãos romanos. Nessa situação, para proporcionar um tratamento igual para aqueles não incluídos no direito da cidade, ou mesmo cidadãos, para situações não tuteladas pelo direito quiritário, o magistrado recorria a uma ficção jurídica que autorizava a sua aplicação analógica (SALGADO, 2006, p. 239). Isto ocorreu com a usucapião de res mancipi, a actio furti, ação de dano injusto, entre outras ${ }^{18}$. Portanto, a realização da justiça, como aequitas, enquanto garantia de igualdade de tratamento, reclama a analogia como meio mais apropriado:

A ratio legis deve ser a mesma ratio decidendi, na medida em que os casos sejam semelhantes. A semelhança está entre os casos, o previsto no suporte fático da hipótese da lei e o não previsto. A igualdade está na consideração dos destinatários e na identidade na ratio. Desse modo, a partir da similitudo casi, pela paritas qualitatis, alcança-se identitas rationis ou a causa idêntica, o fundamento comum entre a lei e a decisão com o fim de realizar o justo, ou seja, de tratar igualmente os que se colocam em situações iguais. (SALGADO, 2006, p. 242)

Em outras palavras, há a constatação da mutabilidade social inevitável e das limitações humanas. Ao aplicador resta cogitar, na situação atual, os objetivos fundamentais da lei previamente elaborada e sua aplicabilidade ao caso diverso posto em apreciação. A conclusão positiva enseja a aplicação de lei já existente. Se negativa, isso não leva necessariamente à recusa da tutela jurídica, como ocorria no sistema processual das ações da lei, mas pode gerar a criação de nova norma. Esse exame, por sua complexidade, deve ser cauteloso para não incorrer em erros que produzam consequências maiores que as já vislumbradas com a simples omissão ou aplicação indiscriminada da norma existente. A quem couber essa análise, deve ser prudente.

Prudentia é um conceito que não foi bem definido pelos romanos até os últimos séculos da República. Contração de providentia, previdência, conhecimento do futuro, sua aplicação primeva era voltada substancialmente para atos com consequências jurídicas, originando-se disso a expressão iuris prudentia e a associação da prudentia aos juristas. Segundo Cape Jr. (2003, p. 37), nos escritos dos primeiros séculos é mais fácil encontrar o adjetivo imprudens, aplicado para descrever homens jovens, podendo-se inferir que a prudentia era

a qualidade de uma pessoa mais velha com experiência prática e um conhecimento do direito, uma habilidade para discernir o certo e o errado, a capacidade de prever as consequências da própria ação, e uma inclinação para se fazer o que é adequado. Prudentiaé também associada ao discurso; o prudens sabe quando falar e quando permanecer calado. (tradução nossa)

Por sua natureza eminentemente prática, como conhecimento obtido da experiência, a prudentia era qualidade altamente respeitada pelos romanos. Entretanto, até a época de Cícero, no discurso público, ela era subordinada à sapientia, termo mais amplo para “sabedoria”, mas essa distinção não era clara no uso cotidiano. Até mesmo sapientia não significava sabedoria filosófica, mas, derivada de sapere, "provar", expressava também a ideia de aprendizado pela experiência. A equivalência entre ambas as palavras, para Cape Jr. (2003, p. 39), parece ter se

${ }^{18}$ Vide GAIO, Inst., IV, 32-38. Cf. CORREIA; SCIASCIA, 1951, p. 234-239. 
originado de uma "tentativa de Cícero para elevar o ideal romano tradicional e prático do prudens ao status do ideal filosófico grego de sapiens". Ademais, não havia correspondência explícita entre prudentiae phronesis, o que pode ter ocorrido a partir da intensificação da influência helênica no fim da República, entre outros, pelos próprios escritos de Cícero (De off., I, 153).

Com efeito, no escrito juvenil De inventione, Cícero arrola a prudentia como uma das quatro virtudes cardinais, definindo-a como "o conhecimento das coisas boas e más, ou nem boas ou más" (II, 159-160, com adaptações). No De oratore, por sua vez, tenta conciliar o fato de que os romanos valorizavam mais a opinião de um vir prudens do que a oratória de um homem instruído e eloquente, enquanto os filósofos gregos afirmavam que todas as boas qualidades atribuídas à oratória pertencem à filosofia (CAPE JR, 2003, p. 45). Na obra, Crasso aponta que o orador deve conhecer "a natureza dos homens, seu caráter, os métodos com que se incitam e reprimem as mentes dos homens, a história, a antiguidade, a administração do estado" (CÍCERO, De orat., I, 165), além do direito civil, o que expressaria uma nova concepção de prudentia. Precisamente, ela é virtude necessária ao melhor orador, dotado de experiência prática e conhecimento teórico, logo, um vir prudens, que se dedica ao conhecimento de todas as coisas, o que coloca como idênticos prudentia e sapientia (CÍCERO, De orat., II, 5-6; CAPE JR, 2003, p. 44-46). No De re publica, a prudentia é a primeira das virtudes do melhor estadista (CICERO, De rep., II 67; CAPE JR., 2003, p. 52 et seq). Finalmente, com o alvorecer do Império, a prudentia é substituída pela sapientia, agora sabedoria absoluta, como virtude do líder político, assumindo em escritores posteriores, especialmente Sêneca e Tácito, o sentido de meios de acomodação do regime político vigente (CAPE JR., 2003, p. 60-61).

De um ponto de vista propriamente jurídico, prudentia é agir com ponderação, considerar as diferentes perspectivas, mensurar os pontos positivos e negativos, visualizar as consequências do ato, escolher com cautela os meios mais propícios a fim de obter o melhor resultado. É uma qualidade indissociável da figura do homem sábio e diligente. $\mathrm{O}$ ato é aqui racionalmente ponderado. Os iurisprudentes tinham amplo conhecimento sobre o direito e pela habilidade de conseguir dar respostas precisas e coerentes às consultas que the são feitas, a partir dos saberes e da experiência assentada durante anos de prática, sem olvidar dos exempla dos grandes juristas e magistrados do passado e do respeito aos mores maiorum.

O magistrado também devia ser vir prudens, pois lhe era exigida a criação e aplicação do direito cotidianamente. Nem todos os magistrados eram iurisprudentes, embora geralmente tivessem formação em direito básica na juventude, a partir do acompanhamento das sessões de consultas daqueles, aos quais não deixavam de recorrer com frequência no exercício de suas funções. Nesse sentido, Salgado descreve como o exercício elaborativo da lei, em sentido amplo, é um ato de prudência: 
A lei é a manifestação da vontade consciente, isto é, nos seus momentos constitutivos presente a ratio: a representação do fim, da sua razão de ser, a deliberação sobre o valor desse fim e os meios para alcançá-lo, vale dizer, a escolha (proairesis de Aristóteles) dos meios adequados à consecução dos fins sociais propostos. Essa escolha é feita mediante a recta ratio, que pondera sobre seus meios, a fim de se alcançarem os fins sociais por ela valorados que são o bem da sociedade de Roma. Assim, a escolha mediante a recta ratio, que se faz pela ordenação ou direção da voluntas pela ratio, refere-se ao modelo de conduta, isto é, a ratio orienta ou dirige a escolha do modelo de conduta e da consequência desse modelo ou da norma, a qual é a medida posta pela ratio. Não se trata de uma razão qualquer exercitada em meio às afecções sensíveis de que falará Kant, mas da razão pura que, na medida em que é diretiva, normativa, não sofre as sinuosidades dos interesses particulares, é recta, tanto porque conhece o bem e dirige a ele a vontade, quanto porque, sendo pura a razão, só pode dirigir a vontade corretamente. E, segundo o homem alcance o exercício dessa recta ratio, será ela tão e pura quanto a de Júpiter, isto é, a mesma é a razão do homem e a de um deus, motivo por que, para Cícero, poderá ele criar leis tão justas quanto Júpiter. (SALGADO, 2006, p. 162-163)

Com efeito, a prudentia iurisé uma sabedoria prática decorrente da experiência dos sábios, que cultivam a recta ratio. Assim, a lei não é apenas vontade (voluntas), mas força da razão, que orienta a escolha, o que possibilita a criação de leis justas, portanto, leis naturais. Por isso Cícero afirma que a "lei é a razão suprema, ínsita à natureza, que ordena o que se deve fazer e proíbe o contrário (...), confirmada e desenvolvida pela mente humana (...)" (CÍCERO, Deleg, I, 6). Somente os sábios, homens prudentes, são capazes de criar leis justas pela recta ratio (SALGADO, 2006, p. 163-164) ${ }^{19}$ :

a prudência é uma lei consistente em exigir as ações boas e proibir os delitos. Julgam que se chama como o nome grego porque atribui a cada um o que é seu, e eu de 'escolher' [a legendo; legere]. Assim, eles fazem consistir a lei na equidade [aequitatis] e nós na eleição, mas uma e outra coisa são próprias da lei. (...) [a lei] é a força da natureza, é o espírito e a razão do homem prudente [ratioque prudentis], é a regra do justo e do injusto. (CíCERO, Deleg, I, 6$)^{20}$

Entretanto, Salgado (2006, p. 164) ressalva que, "se a elaboração da lei como norma geral é tarefa do sábio, da recta ratio cultivada, não quer isso dizer que o homem comum não possa agir corretamente", ao que então recorre ao conceito de boa-fé. Fides é vinculação à palavra dada, lealdade, sinceridade, consciência, retidão, confiança (FARIA, 162, p. 397). Para Cícero, fides parece ter esse nome justamente porque "o que é dito acontece" (fit quod dicitur) (CÍCERO, De rep., IV 7c). Pode ser compreendida também como "colaboração e auxílio mútuo (na relação entre iguais) e como amparo ou proteção (na relação entre desiguais)" (MARTINSCOSTA, 2015, p. 49), implicando credibilidade em relação a alguém e, reciprocamente, um "estado de confiança" do sujeito titular da fides (SALAZAR REVUELTA, 2015). É um aspecto da constantia, uma das principais virtudes do homem romano, como manutenção da palavra, independentemente da forma pela qual foi dada

\footnotetext{
${ }^{19}$ PAPINIANO. D. I, 3, 1. Cf.JUSTINIANO, 1889, p. 209: "A lei é o preceito comum, decisão dos homens prudentes, coerção dos delitos que são praticados espontaneamente ou por ignorância, garantia comum da república.” (Lex est commune praeceptum, virorum prudentum consultum, delictorum, quae sponte vel ignorantia contrahuntur, coercitio, communis reipublicae sponsio.).

${ }^{20}$ Tradução nossa cotejada com a espanhola.
} 
(SCHULZ, 1936, p. 224). Fides aproxima-se ainda muito da noção de honestidade, de modo a incluíla em seu espectro semântico, pois agir de boa-fé é agir honestamente, manter a fé de acordo com os costumes (SCHULZ, 1936, p. 228). De fato, viver honestamente é um preceito do direito, segundo Ulpiano (D. I, 1, 10, \$1 ${ }^{21}$, romanização de regra moral oriunda dos estoicos gregos (MATOS, 2009, p. 290-291), para os quais o honestum reúne todas as demais virtudes (CÍCERO, De fin., III, 7), de forma que, vivendo honestamente, alcança-se a perfeição, pois se conforma ao logos, ressalvado que nem tudo o que é honesto é necessariamente lícito (PAULO, D. L, 17, 144).

Em suas raízes, a fides estava conectada à veneração divina, como juramento de cunho religioso, iusiurandum. Inclusive, é frequente a sua personificação e deificação, como a deusa Fides. Ela então emerge nas relações jurídicas entre os particulares, imprimindo certa segurança ou certeza (SALAZAR REVUELTA, 2015, p. 118-120 ${ }^{22}$. Com o tempo, os juramentos deixam de ter importância, uma vez que não mais se teme a punição dos deuses pela quebra ou falsidade, mas a pessoa se mantém vinculada pela fides (SCHULZ, 1936, p. 228; CÍCERO, De off., III, 104). Independentemente da correção histórica desta interpretação, fato é que, para os romanos, a fides chegou a ser considerada a coisa mais sagrada na vida (fidem sanctissimam in vita qui putat) (CÍCERO, In Verrem, II, 3, 3-6), devendo ser observada mesmo quando a palavra é dada ao inimigo que não partilha desse mesmo valor (CÍCERO, De off., I, 39).

Para Bonfante (2011, p. 189-218), a bona fides é um conceito ético e social, assumido pelo direito, mas que não o altera pela lei. Assim, a lei se refere a uma bona fides naturalis, e não civilis. Ela é medida pelo senso moral da sociedade, pela prática da vida diária, remetida de tempos em tempos à apreciação do juiz, partícipe e intérprete desse senso. Era o que hoje entendemos por honra e virtude (honrae virtustinham valor diferente, mais extrínseco e material), significando "a mais austera observância do próprio dever nas relações com os próprios semelhantes". Assim, a bona fides nada mais é do que a fides romana, não significa crença, mas verdade e honra. Como conceito ético, o momento psicológico não está excluído, sendo frequente o uso entre os romanos dos termos credere, putare, existimare, scire, scientia ou conscientia, ignorare, nescire. Nesse sentido, também o dolus, ao qual geralmente é oposta a bona fides, é conceito ético, o que leva a concluir pela insuficiência de sua definição pela via negativa, como mera ausência de dolo ou má-fé. Partindo de outra perspectiva, Salgado defende que fides é sim crença de agir, porém, ação segundo a recta ratio, o que é ser verdadeiro. É adequação rigorosa "da expressão

\footnotetext{
${ }^{21}$ Cf. JUSTINIANO, 1889, p. 199: "Iuris praecepta sunt haec: honeste vivere, alterum non laedere, suum cuique tribuere." Também reproduzido em Institutiones, I, 1, \$3.

${ }^{22}$ Sobre o culto da deusa Fides, afirma ainda: "De maneira que, se partimos do ritual do culto à deusa Fides, observamos que o fato de os sacerdotes maiores cobrirem sua mão direita com um véu de linho branco, entende-se como um gesto que expressa a integridade que supõe seguir a fides nos pactos que vêm concluídos e aperfeiçoados simplesmente com a palavra dada e o estreitamento da mão direita, distante de todo formalismo" (tradução nossa).
} 
com a intenção, da ação com o discurso, do fazer com a palavra”, mas que considera as circunstâncias de formulação e manifestação da vontade, além das mudanças de conjuntura que afetam as consequências da realização do objeto acordado para as partes (SALGADO, 2006, p. 164-165).

A fides é a primeira forma de justiça, por isso a afirmativa de Cícero de que "o fundamento da justiça reside não obstante na boa-fé [ fides], isto é, na constância e na verdade [ constantia et veritas] nos compromissos assumidos" (CÍCERO, De off., I, 23, com adaptações). Assim, desdobra-se em sinceridade da palavra e em cumprimento da promessa (SALGADO, 2006, p. 164), extremamente importantes para o direito privado, e ainda leva a duas regras importantes: o magistrado que elabora um édito a ele está vinculado e as normas jurídicas não possuem força retroativa ${ }^{23}$. As aplicações jurídicas da boa-fé são numerosas, traduzindo-se como conceito valorativo (fidei bonae nomen), cláusula formular de tutela da atividade negocial (oportere ex fide bona e iudicia bonae fidei) e princípio de integração dos deveres contratuais (bonae fidei interpretatio e bonum et aequum) (MARTINS-COSTA, 2015, p. 50). A partir dela, novas ações foram introduzidas pelos pretores, apoiados pelos jurisconsultos, como as actio commodati, depositi, fiduciae, pigneraticia, empti, venditi, locati, conducti, prosocio, mandati, negotiorum gestiorum, tutelae etc. Todas elas tinham em comum a presença, na intentio da fórmula, da expressão ex fide bona, "que deixava ao juiz uma ampla margem de manobra para apreciar, de uma maneira equitativa, as obrigações resultantes" (SALAZAR REVUELTA, 2015, p. 122-123).

Enfim, nota-se que é justamente ao observar a utilitas e empregar a analogia, considerando a fides, no recurso à aequitas, que se pode dizer, seja do elaborador, seja do criador do direito, que este deve ser vir prudens.

\section{A AEQUITAS NA ELABORAÇÃO E NA APLICAÇÃO DO DIREITO: IUS GENTIUM E IUS PRAETORIUM}

A presença da aequitas no direito romano não foi marcante em toda a sua história. Sua ascensão ocorreu no período clássico, tradicionalmente situado entre os séculos II a.C. e III d.C. ${ }^{24}$, como delineado ao longo dos tópicos anteriores. Entretanto, para expor um quadro minimamente completo da aequitas, é imprescindível verificar o seu funcionamento nas mãos dos juristas e magistrados, nos momentos de elaboração e aplicação do direito, de certo modo indissociáveis, e isso significa, em outros termos, compreender a interpretação do direito.

Nos primeiros séculos de Roma, o direito surge predominantemente das forças sociais no transcurso do tempo, como normas consuetudinárias, nas quais estão imiscuídos teor religioso e natureza propriamente jurídica, e também pelo esforço consciente de fornecer respostas a problemas que eclodiam ou mesmo para evitá-los. Em

\footnotetext{
${ }^{23}$ SCHULZ, 1936, p. 229: "O criador de uma regra deve manter sua palavra; deve ser possível confirmar na lei como ela é, as consequências jurídicas dos próprios atos devem ser previsíveis” (tradução nossa).
} 
todo o caso, assim é constituído o ius civile, o direito da cidade, mais precisamente dos seus cidadãos. Como assevera Mommsen, é o direito de uma comunidade de desenvolvida agricultura e comércio, que valoriza a liberdade e a expressão da vontade (voluntas), mas a afirmação do romanista sobre o rápido abandono da proteção dos usos antigos e dos simbolismos deve ser vista com reservas (MOMMSEN, 1862, p. 167-168). Nesse período, o fas e o ius eram preservados pelos pontífices, os quais realizavam modificações no ius civile, embora comedidas, por meio da interpretatio. Então detentores do monopólio dos conhecimentos especiais e secretos acerca dos muitos ritos que permeavam a vida dos romanos (TITO LÍVIO, IX 46, 3-7), o que impunha um caráter sacro, entre outros, aos atos jurídicos, exerciam eles influência constante na vida dos cidadãos. No cotidiano citadino, eventos inesperados ou imprevisíveis requisitavam respostas eficientes para o bom andamento das relações sociais e a interpretação era a alternativa para se valer das velhas formas tradicionais a novos fins sem, contudo, desrespeitar as normas tradicionais com suas formas sacramentais (CORNIL, 1930, p. 28).

Mesmo com a intensificação do afastamento da índole sagrada, o rigor do ius civile permaneceu, em detrimento do florescimento da sociedade e do intrincamento dos laços interpessoais. O principal exemplo provém da Lei das XII Tábuas, promulgada em meados do século V a.C., que fixou parte substancial do direito costumeiro vigente, e caracterizada pelo formalismo e pela rigidez. Se na sua implementação representou a conquista dos plebeus de segurança jurídica e de relativa igualdade perante a lei, frente aos patrícios, com o tempo a aplicação de suas disposições tornou-se fonte de injustiças. Com efeito, quando alguém se sentia lesado, para intentar a intervenção do pretor, necessitava que uma ação estivesse prevista. O que modernamente denomina-se direito material ou substancial e direito processual eram fundidas. Assim, somente era titular de uma actio quem "lograsse demonstrar, nos esquemas preestabelecidos, uma situação de direito material realmente existente" (TUCCI; AZEVEDO, 2013, p. 40). Como resume Villey (1949, p. 13), "o cidadão romano que intenta uma ação, deve necessariamente submeter-se a ritos; utilizar um dos rituais formalistas". As ações das leis (legis actiones) logo se tornaram insuficientes para atender às demandas da realidade em contínua transformação. Novas situações permaneciam desprotegidas pelo ius civile, uma vez que as ações eram típicas e escassas (VILLEY, 1949, p. 44-45), enquanto outras, conquanto tuteladas, ficavam desamparadas por equívoco na prática de algum ato. É memorável o que conta Gaio a respeito:

As ações usadas dos antigos chamavam-se ações da lei, seja por se originarem das leis, pois no tempo não existiam ainda os éditos do pretor, introdutórios de várias ações, seja por se conformarem às palavras das próprias leis, conservando-se por isso imutáveis como as leis mesmas. Daí o ter-se respondido que perdia a ação quem, agindo por causa de videiras cortadas, mencionara videiras [vites], pois a lei das XII Tábuas, na qual se fundava a ação por videiras cortadas, falava de árvores [arboribus, arbores] cortadas em geral. (GAIO, Inst., IV, 11. Cf. CORREIA; SCIASCIA, 1951, p. 225, com adaptações)

\footnotetext{
${ }^{24}$ Conforme proposta de Cuq, preferida também por Peixoto, vide CUQ, 1928, p. 3; PEIXOTO, 1997, p. 4-9.
} 
Mas todas estas ações da lei tornaram-se a pouco e pouco odiosas. Pois, dada a extrema sutileza dos antigos fundadores do direito, chegou-se à situação de quem cometesse o menor erro, perder a causa. Por isso, aboliram-se as ações da lei pela lei Ebúcia e pelas duas leis Júlias, levando os processos a se realizarem por palavras fixas, isto é, por fórmulas. (GAIO. Institutiones. IV, 30. Cf. CORREIA; SCIASCIA, 1951, p. 235, com adaptações)

Outrossim, as cinco ações elencadas na Lei das XII Tábuas, legis actio per sacramentum, legis actio per iudicis arbitrive postulationem, legis actio per condictionem, legis actio per manus iniectionem e legis actio per pignoris capionem, podiam ser invocadas apenas por cidadãos romanos, isto é, o pater familias, segundo o ius quiritarium, dos quais estavam excluídos os filhos, as mulheres, os escravos, os incapazes e os estrangeiros. A presença maciça destes últimos, em crescente contato com os romanos, seja por meio dos territórios conquistados, seja pela atração à florescente Roma, para comerciar ou habitar, ensejou a criação de uma magistratura específica, em torno do século III a.C. O pretor peregrino, ao qual foi atribuído cuidar dos casos envolvendo romanos e estrangeiros, ou estrangeiros entre si, não tinha, a princípio, um direito próprio a aplicar, o que o levou a se espelhar no ius civile para dizer o direito, possibilitado por exercer o imperium. Nasce disso o ius gentium positivo, direito mais maleável e flexível, a atender principalmente as exigências mercantis (PEIXOTO, 1997, p. 244-245), sem formalidades excessivas e "nivelador", quando comparado às dicotomias rígidas e excludentes do direito civil ${ }^{25}$. Era uma questão de justiça, tratar igualmente situações idênticas, quer dizer, fazer triunfar a aequitas frente às concepções formalistas do direito antigo (FALCÓN Y TELLA, 2005, p. 52-53), valendo-se da analogia e apreciando a boa-fé.

Em pouco tempo, também o pretor urbano, competente para julgar pleitos envolvendo cidadãos romanos, segundo o ius quiritarium, recorreu ao seu imperium e ius edicendi para sanar situações recusadas ao amparo jurídico. A Lex Aebutia (149-126 a.C.) admitiu parcialmente o processo formulário para o julgamento de causas decorrentes de relações inter cives, permitindo às partes escolherem entre as ações da lei e a fórmula contida no édito do pretor (SCIALOJA, 2012, p. 189). Há diferentes posições acerca da origem desse gênero de processo, porém, em resumo, pode-se afirmar o seu nascimento no vigor das ações da lei, como alternativa menos formal e mais dinâmica, não obtendo reconhecimento legislativo imediato, o que somente ocorreu tempos depois com o advento da lei mencionada (TUCCI; AZEVEDO, 2013, p. 62-64). As fórmulas (diminutivo de "forma", em grego significando "modelo") eram modelos abstratos que o pretor incluía em seu édito (edictum), documento em que dizia (edicere) o direito, definindo regulamentos e prescrições, afixado publicamente no início de seu mandato. Realizada a comunicação prévia ao réu da pretensão pelo demandante (editio formula) e o

\footnotetext{
${ }^{25}$ A produção por pretor romano do ius gentium, além das sucessivas expansões da cidadania, fez com que se perdesse a essência dessa distinção com o tempo. Vide CÍCERO, De off., III 69: “(...) desejaram os nossos antepassados que fosse uma coisa do domínio do direito das gentes enquanto outra, do domínio do direito civil. Aquilo que pertence ao domínio do direito civil não será
} 
seu chamamento a juízo (in ius vocatio), presentes as partes perante o magistrado, a pretensão era então formalmente apresentada (editio actionis), seguida da indicação da fórmula constante no édito (postulatio actionis). O réu expunha a sua defesa e, não havendo hipóteses de encerramento do processo, designava-se o iudex (iudicium dare) em comum escolha entre o pretor e os pares e redigia-se a fórmula específica para o caso em questão, também com participação dos três, com os dados indispensáveis para o julgamento da causa pelo iudex na etapa seguinte. $\mathrm{O}$ autor obtinha a aceitação do réu e ambos se comprometiam a litigar nos limites da fórmula fixada (litis contestatio), o que colocava fim à fase in iure (TUCCI; AZEVEDO, 2013, p. 65 et seq).

Neste momento inicial descrito, novas margens para a realização da justiça, a partir da aequitas, foram abertas. Logo ao apresentar a sua pretensão (intentio), o pretor podia verificar a incongruência do pedido, se ausente de lastro jurídico ou eivado de algum outro problema, não concedendo a ação (denegatio actionis), o que também podia ocorrer após a defesa do réu. Nesta, o acusado tinha a oportunidade de opor exceptiones, originadas das praescriptiones pro reo (TUCCI; AZEVEADO, 2013, p. 78-79), parte da fórmula destinada a submeter ao iudex certas objeções do réu (CARRÉ DE MALBERG, 1887, p. 93). A praescriptio era uma parte adjeta da fórmula, em geral inserida por iniciativa do autor (praescriptio pro actore), que buscava delimitar o objeto do litígio para, assim, evitar que o seu direito fosse atingido pela eficácia extintiva da litis contestatio (que, em caso de pluris petitio, podia gerar consequências negativas graves, ou obstar o intento de nova ação fundada no mesmo negócio) (TUCCI; AZEVEDO, 2013, p. 78). Mas essa espécie de praescriptio mostrou-se insuficiente, de modo que o pretor criou um mecanismo que obrigava o iudex a examinar, ao mesmo tempo, a intentio do demandante e os meios de defesa do réu, colocando em exame duas questões litigiosas em uma instância única (CARRÉ DE MALBERG, 1887, p. 95). Assim, a exceptio consistia em uma cláusula condicional negativa, por meio da qual podia alegar qualquer circunstância em favor de seu direito (TUCCI; AZEVEDO, 2013, p. 79), sem negar a pretensão do autor, opõe a ela um fato distinto que lhe anula o efeito (NÓBREGA, 1962, p. 662-663). Como afirma Gaio, "as exceções foram introduzidas em defesa dos réus. Pois, como muitas vezes sucede pode uma pessoa ser acionada segundo o direito civil, constituindo entretanto uma iniquidade condená-la [sed iniquum sit eum iudicio condemnari]" (GAIO. Inst. IV, 116. Cf. CORREIA; SCIASCIA, 1951, p. 266-267). Na mesma linha, Ulpiano registra que "com muito mais razão dirá alguém, que aí mesmo a quem damos as ações compete também a exceção" (ULPIANO. D. L, 17, 156, \$1º). As alegações do réu em exceptio podia ser afastada pelo autor por uma replicatio, e esta, pelo réu, por uma duplicatio e, finalmente, o autor podia opor ainda uma triplicatio (GAIO. Inst., IV, 126-129. Cf. CORREIA; SCIASCIA, 1951, p. 270-271; TUCCI; AZEVEDO, 2013, p. $80)$.

necessariamente do domínio do direito das gentes e, não obstante, aquilo que é do domínio do direito das gentes será também 
Além disso, para pôr fim a certas injustiças advindas da evolução da vida social, os pretores desenvolveram meios processuais complementares de tutela, a partir de seu imperium.

Os interdicta eram ordens emanadas pelo magistrado, a pedido de um cidadão e dirigido a outro, proibindo a realização de determinado ato (proibitório), a restituição de certa coisa (restitutório) ou a exibição, perante ele, de coisa ou pessoa sobre a qual se discutia a liberdade (exibitório). Eram situações de fato que mereciam a proteção jurídica e, para tanto, o magistrado baseava-se no pressuposto de veracidade dos fatos alegados pelo requerente da ordem, concedendo tutela provisória (MOREIRA ALVES, 2014, p. 248-249). Lages, respaldado em diversos jusromanistas, afirma que as interdicta representam as primeiras intervenções pretorianas criativas, ainda antes do advento da Lex Aebutia (LAGES, 1949, p. 48), e encerraram diversas controvérsias envolvendo posse e quase-posse, matérias não tratadas na Lei das XII Tábuas (LAGES, 1949, p. 49; GAIUS, Institutas, IV, 139 Cf. CORREIA; SCIASCIA, 1951, p. 274-275; JUSTINIANO, Inst., IV, 15). A posse era considerada pelos romanos um fato, diversa da propriedade (nihil commune habet proprietas cum possessione; separata esse debet possessio aproprietate) (D. XLI, 2, 12, 1; D. XLIII, 17, 1, 2), mas que, conforme as condições concretas, impendia receber proteção jurídica, o que começou a surgir, por exemplo, com os interditos possessórios. O próprio ius civile já atribuía consequências jurídicas a algumas situações envolvendo a posse, como a aquisição de direito de propriedade por usucapião (logo, uma possessio civilis) (MOREIRA ALVES, 2014, p. 273 et seq). Todavia, a substancial tutela e efeitos jurídicos da posse originaram-se dos esforços pretorianos, que salvaguardavam a obtenção, a conservação ou a restituição da posse por intermédio dos interdicta.

As stipulationes, por sua vez, consistiam em obrigações nascidas de procedimento no qual, a pedido de um interessado, o magistrado ordenava mediante um decreto (iussum cavendi), após a análise das alegações, alguém a estabelecer um vínculo jurídico com o postulante por meio de uma stipulatio, contrato verbal e solene, impondo até meios coercitivos indiretos para compelir a parte. As obrigações resultantes eram iuris civilis, ou seja, reconhecidas pelo direito civil e protegidas pela actio ex stipulatio (MOREIRA ALVES, 2014, p. 250-251; TUCCI; AZEVEDO, 2013, p. 94-95). Outro mecanismo jurídico elaborado foi a missio in possessionem, resolução pretoriana que, a requerimento de um interessado, autorizava a imissão na posse de bens de outrem nas hipóteses previstas no édito, com finalidade acautelatória, preparatória ou coercitiva (MOREIRA ALVES, 2014, p. 251; TUCCI; AZEVEDO, 2013, p. 93-94). Por fim, a restitutio in integrum era ato pelo qual se considerava não realizado negócio jurídico ou formalidade processual que eram válidos para o ius civile, porque os efeitos eram iníquos, por prejudicarem uma das partes. Assim, o pretor determinava o retorno ao estado anterior, denegando

necessariamente do domínio do direito civil." 
ou concedendo ações que surgiam desses negócios, mas desde que o único meio para a reparação dos danos. Essa criação é uma das que mais claramente tem em vista a aequitas, uma vez que considera como não realizados negócios jurídicos ou formalidades processuais regularmente executados aos olhos do ius civile, ponderando causas como idade (obaetatem), erro (oberrorem), coação (obmetum), dolo (obdolum), fraude contra credores (obfraudem creditorem), entre outros (MOREIRA ALVES, 2014, p. 251-252; TUCCI; AZEVEDO, 2013, p. 9597).

Pode-se também ilustrar como produto da atividade pretoriana a propriedade bonitária (in bonis esse ou in bonis habere), fruto da proteção concedida a pessoa que comprara uma res mancipi e recebera a coisa por simples traditio, sem passar pelo rito da mancipatio ou da in iure cessio. Com isso, o vendedor permanecia titular segundo o direito quiritário e poderia reivindicar o bem do comprador. Assim, o pretor criou a exceptio rei venditae et traditae, exceção que, apesar de impedir a requisição da coisa, não garantia o domínio do adquirente, a depender do transcurso do prazo de usucapião. Então, havia uma dupla espécie de propriedade, quiritária (do vendedor) e bonitária ou pretoriana (do comprador, que podia defender a coisa), o que somente foi resolvido com a criação da actio publiciana, pelo pretor Publício, que considerava na fórmula a ficção de que o proprietário bonitário já teria adquirido, por usucapião, a titularidade segundo o direito civil (MOREIRA ALVES, 2014, p. 295-296).

As elaborações pretorianas que se inclinam à justiça não se resumiram a hipóteses processuais, repercutindo também na fundamental noção de pessoa. No direito arcaico, o cidadão é o homem adulto livre, chefe de um grupo familiar, dotado dos direitos políticos de voto (ius suffragii) e de elegibilidade para magistraturas (ius honorum) e dos direitos privados de casamento (conubium), comerciar e obrigar-se (commercium) e de fazer testamento ou figurar como testemunha ou herdeiro (factio testamenti) (GIRARD, 1906, p. 106; PEIXOTO, 1997, p. 308). O pater familias gozava de poderes absolutos sobre os filhos, a mulher, os escravos, tão amplos que incluem a decisão sobre a vida e a morte (ius vitae nescisque). Entretanto, ao longo dos séculos, esse poder foi limitado, seja pelos costumes, seja por medidas efetivas, ao passo que certas prerrogativas foram conquistadas ${ }^{26}$. Entre o fim da República e o Principado, os filhos passaram a ter liberdade de praticar alguns atos e comprometer o pater (até, depois, a si próprio, como em D. 44, 7, 39), além de dispor de bens próprios adquiridos enquanto soldado (peculium castrense) (DUCOS, 2007, p. 64 et seq). Em relação à mulher, foram reconhecidas certas capacidades negociais, sem a necessidade de tutela do pai ou do marido, a administração de bens, assim como o casamento sine manu, fundado no consensus dos esposos ${ }^{27}$. O poder do pai e do esposo foram limitados (D. 48, 5, 23, 4), já no fim da República o tutor não tinha mais de administrar o

${ }^{26}$ Vide PAPINIANO. D. XXXVII, 12, 5; MARCIANO. D. XLVIII, 9, 5. Cf.JUSTINIANO, 1897, p. 62-63; 757. 
patrimônio da mulher, embora ela ainda necessitasse dele para diversas questões (DUCOS, 2007, p. 70-75) ${ }^{28}$. Estas e outras modificações, inclusive numerosos abrandamentos ao tratamento dos escravos, foram aprofundadas no período imperial, menos pelo direito pretoriano do que por constituições dos imperadores, em virtude da influência do estoicismo e, posteriormente, do Cristianismo.

Como se nota, existia uma função negativa (vetus) da aequitas, na denegatio actionis e nas exceptiones, além de uma função positiva (novum), de aplicação de norma de ius civile a casos não abarcados (FALCON Y TELLA, 2005, p. 54) ou pela criação de fórmulas inteiramente novas, sem ligação com o ius civile, fórmulas in factum, para proteger situações não previstas pelo direito antigo (VILLEY, 1949, p. 29). As situações enumeradas deixam visível o caminhar progressivo para um tratamento igualitário de categorias de pessoas cujas distinções se mostravam, no cotidiano, insustentáveis, ainda que tal igualdade nunca tenha sido atingida em plenitude. Carré de Malberg questiona por que o povo não fazia ele mesmo essas reformas, dependendo da intervenção pretoriana? Para o autor, a aequitas estava situada no domínio do direito, em outros campos ela não seria limitada ou orientada por princípios imutáveis e invioláveis (CARRÉ DE MALBERG, 1887, p. 92), mas esta explicação é excessivamente jurídica.

A consciência jurídica reage à consciência social, consolida novos valores e carências da sociedade, que a realidade cambiante, com suas inúmeras peculiaridades e imprevisibilidades, impõe. Os romanos percebem a impossibilidade de uma absoluta "igualdade de condições entre os homens, pois esta igualdade é uma pura quimera”: a única igualdade possível "é a igualdade perante a lei e perante a justiça” (DEMANGEAT, 1876, p. 8). E ainda ela é limitada. O direito positivo é um espelho imperfeito da razão que rege o universo, assim, em prol do imperativo da justiça, a aequitas pode prevalecer sobre a lei humana (CÍCERO, De orat., I, 240). Como afiança Paulo, em todas as coisas, principalmente no direito, deve observar-se a aequitas (In omnibus quidem, maxime tamen jure aequitas spectanda est) (PAULO, D. L, 17,90). Isso não é ignorar o direito posto, em sua sacralidade e lastro histórico. O ius praetorium é, justamente, o direito que os pretores introduziram para auxiliar ou suprir ou corrigir o direito civil para a utilidade pública (adiuvandi vel supplendi vel corrigendi iuris civilis gratia propter utilitatem publicam) (PAPINIANO, D. I, 1, 7, 1). Ou seja, a mitigação do rigor da lei não a alterava, ou ab-rogava um princípio do direito civil, mas criava lateralmente uma regra nova (PETIT, 1903, p. 29) ${ }^{29}$. "Sem embargo, o que se omitiu nas leis não se omitirá pela retidão dos julgadores (non omitetur religione iudicantium) (...)”

\footnotetext{
${ }^{27}$ NERÁCIO. D. XXXV, 1, 15. Cf.JUSTINIANO, 1892, p. 208; ULPIANO. D. L, 17, 30. Cf.JUSTINIANO, 1897, p. 947.

${ }^{28}$ Bauman (1994, p. 45-52) aponta que existiam mulheres atuavam como jurisconsultos, apesar de suas opiniões não "tinham a mesma capacidade de fazer direito que os responsa dos práticos homens”, recolhendo diversos registros.

${ }^{29}$ CHAMOUN, 1951, p. 18-19: "O curioso é que o velho ius civile permanece, imune dos novos influxos, estanque e formalista, até os imperadores; mas pode permanecer porque o direito pretoriano se constituiu à sua olharga, trabalhando sobre princípios às vezes antagônicos, portanto, equilibrando-o."
} 
(PAPINIANO, D. XXII, 5, 13) e, “(...) também a aquelas ações, que estão manifestas nas leis, se a lei fora justa e necessária, as supre o Pretor o que falta a lei (supplet Praetor in eo, quod legi deest) (...)" (POMPÔNIO, D. XIX, 5, 11). De certo modo, o direito honorário é viva voxdo direito civil (MARCIANO, D. 1, 1,8).

O pretor detinha o imperium, poder supremo no interior da civitas, a ser usado em favor da res publica. Ao estabelecer o direito nessas condições, fazia-o guiado pela prudentia e pela aequitas, na aplicação atualizadora do direito, revestindo-se da autoritas, pois legitimado ontológica e teleologicamente a assim agir (PINTO COELHO, 2009, p. 133). No exercício da iurisdictio, pelo ius edicendi, tinha a possibilidade de romper com o formalismo exagerado, entrave para o desenvolvimento de Roma, e voltar-se para o "momento social" (CARMIGNANI, 2009, p. 118). O édito tem ínsita a correlação entre aplicação e interpretação do direito, voltada à resolução de casos concretos (PINTO COELHO, 2009, p. 144). O edictum perpetuum, de duração anual, podia ser complementado pelo edictum repentinum, para atendimento de problemas não contemplados (até ser proibido pela Lei Cornélia em 67 a.C.). A cada mandado, os novos magistrados ${ }^{30}$, reconhecendo disposições consentâneas com a justiça, mantinham parte substancial do édito anterior (pars translaticia) e adicionavam outras fórmulas e regras. Assim, as contribuições foram se acumulando no decorrer dos séculos, até a concentração de poderes do período imperial cercear as prerrogativas das magistraturas republicanas. A ordo iudicioroum privatorum cedeu lugar à cognitio extra ordinem, conduzida por representantes do imperador e, em 131, Adriano determinou ao jurisconsulto Sálvio Juliano a consolidação definitiva de um edictum perpetuum a partir das disposições tradicionalmente reproduzidas.

Concomitantemente, desenvolveu-se a iurisprudentia, "o conhecimento das coisas divinas e humanas, a ciência do justo e do injusto", como definiu Ulpiano (D. 1, 1, 10, \$2). Não apenas o solo era fértil para prosperarem as reflexões em torno do direito e dos desafios que este enfrentava, como elas eram elementares para as funções primordiais das magistraturas. Como condensa Cuq:

O formalismo está em decadência, a equidade tempera o rigor do direito. Sob a influência da retórica e da filosofia gregas, aparecem, no final do século VIIo [da história de Roma], os primeiros ensaios de elaboração científica do direito. Com os jurisconsultos do Io século do Império, a organização do direito se desenvolve, e sob o reinado dos Antoninos e dos Severos, atinge um grau de perfeição tal que se pôde dar a este período o nome de clássico. (CUQ 1928, p. 3) (tradução nossa) ${ }^{31}$

Também Falcon y Tella reconhece a ligação essencial entre aequitase a jurisprudência romana clássica:

A chamada era clássica do Direito romano, que é o período decisivo em matéria de equidade, deslumbra pela tarefa dos jurisconsultos, mais que como comentaristas de leis,

\footnotetext{
${ }^{30} \mathrm{O}$ édito não se restringiu ao pretor, urbano ou peregrino, mas também sendo instrumento dos edis curules, em Roma, e dos governadores e dos questiones, nas províncias, pois dotados de imperium e de iurisdictio. Cf. GAIO, Inst., I, 6. Cf. CORREIA; SCIASCIA, 1951, p. 18-21; GIFFARD, 1951, p. 47.

${ }^{31}$ Ressalva-se o uso do termo "científica" pelo autor, que deve ser interpretado apenas como precária analogia com a concepção moderna de ciência.
} 
embora também, como fazedores, com seu talento, da jurispridência técnica. $O$ mais grandioso de sua obra, pelo que conquistaram, e conservam ainda hoje, um lugar inegável na história do progresso humano, foi por seu talento para sempre nos casos duvidosos a solução "justa" ou, se se prefere, "equitativa". Os dois elementos cardinais que fazem culminar o Direito romano: o pretor - através do Édito - e os jurisconsultos - através da "iurisprudentia”, entendida como Ciência do Direito ao modo em que é atualmente o termo "jurisprudence" no mundo anglo-saxônico, frente a sua acepção nos sistemas continentais, como sentenças judiciais - se inspiram totalmente nos ditames da equidade. (...) A jurisprudencia, entendida como Ciência do Direito, estava voltada a adaptar o Direito às circunstancias da vida. (FALCON Y TELLA, 2005, p. 56-57)

Em torno do fim da República, os jurisconsultos encontram novos elementos na filosofia grega, após certa resistência do Senado e dos censores em permitir sua livre difusão, notadamente do estoicismo, principalmente a ideia de "um direito inato, fundado na razão e superior às leis escritas", abrindo-se ao tempero da aequitas e a um método de trabalho mais exigente (PETIT, 1903, p. 27). "A aequitas presidindo o mundo das relações sociais" é o ideal dos jurisconsultos romanos, não como conceito doutrinário, abstrato e absoluto, mas como noção realista, enlaçada "a um determinado momento da consciência social" (RAMOS, s/d, p. 28).

O agir próximo dos pretores e dos jurisconsultos proporcionou a concepção de um direito vinculado ao que é racionalmente justo, segundo revelado pela experiência. Esta era uma delicada operação interpretativa, de contínua criação e re-criação (PINTO COELHO, 2009, p. 146; 161), que resultou no "entendimento de que a Justiça se realiza no equilíbrio do binômio segurança/equidade e o desenvolvimento de um sistema teórico sólido, capaz de atingir esse equilíbrio" (PINTO COELHO, 2009, p. 142-143).

Reiterando, aequitas é tratamento igual para situações iguais (e desiguais para as desiguais), é fazer justiça no caso singular, desenvolver o direito em acompanhamento à consciência social, para evitar que se torne ele próprio injusto em razão da desincronia com a realidade (CHAMOUN, 1951, p. 20). Realizar a iustitia, isto é, dar a cada um o seu direito (ius suum cuique tribuendi) (ULPIANO, D. 1, 1, 10, \$1), somente é possível ao se desvelar quem são os sujeitos concretos, com suas características particulares e as circunstâncias componentes da relação colocada em apreciação. A aequitas "não era uma entidade distinta, contraposta ao Direito, mas o próprio Direito" (FALCON Y TELLA, 2005, p. 57). E foi precisamente "sobre o direito de Roma, [que] se edificou o direito do mundo" (SCIALOJA, 2012, p. 190) ${ }^{32}$.

\section{CONCLUSÃO}

Ponderando-se a permeabilidade da aequitas por todo o direito romano, ao menos em sua fase clássica, e sua identificação com a própria ideia de justiça, é possível apontá-la como um princípio fundamental, no sentido de ser noção a orientar a elaboração e a aplicação do direito e, dessa maneira, determinar os novos rumos da 
experiência jurídica romana. Como elemento de harmonização entre a universalidade da lei e a particularidade dos fatos, assim como do sujeito, detentor da situação conflituosa peculiar, perante a ordem social, participa, em última instância, da própria estrutura do direito.

A partir da aequitas, o ius civile pôde ser enriquecido pelo ius praetorium, a rigidez ancestral foi amenizada e, o direito, reconectado com as transformações da realidade. Por meio da atividade pretoriana, em muito embasada na iurisprudentia, foram então elaborados novos institutos jurídicos em resposta às injustiças fáticas, como os interdicta, as stipulationes e as exceptiones, além do próprio ius gentium, do qual ascendeu. E isso somente foi possível por contar com outros princípios auxiliares, a saber, a utilitas, a analogia, a prudentia a fides.

A aequitas afirmou-se como mecanismo de correção do fato frente à lei, tendo em vista as repercussões particulares e sociais geradas e os efeitos jurídicos a ele atribuídos, de modo a efetivar a igualdade nas relações desequilibradas, fornecer tratamento igual a situações iguais, e desigual para situações desiguais. Apesar de sua importância como instrumento balanceador da conexão necessária entre direito e consciência social, no contexto do sofisticado direito romano clássico, a aequitas sofreu profundas reformulações já nos momentos políticos posteriores da história de Roma. Isso gerou o progressivo alijamento da transformada noção de equidade na tradição romano-germânica a um plano secundário do pensamento e da prática jurídica, o que permanece nos ordenamentos contemporâneos. Um minucioso trabalho de recuperação desse princípio para as demandas da configuração jurídica hodierna ainda é necessário e pode partir do resgate da aequitas na experiência fundacional do direito em Roma.

\title{
THE AEQUITAS AS A FUNDAMENTAL PRINCIPLE OF CLASSICAL ROMAN LAW: AN HISTORICAL-PHILOSOPHICAL INQUIRY
}

\begin{abstract}
The article aims to investigate the functions and limits of aequitas in the classical Roman law. From the examination of original sources and juridical and philosophical studies on Latin legal culture, this work has three stages: first, it tries to understand the peculiarity of aequitas in contrast to the Greek and modern traditions; second, it investigates the exercise of aequitas, by its auxiliary principles utilitas, analogy, prudentia and fides; finally, it examines the effects of equity in Rome, in particular on the elaboration and application of law through ius gentium and ius praetorium. Thus, it is revealed how aequitas takes form of a fundamental principle that guides the classical Roman law, responsible for its complexity, prosperity and exemplary force.
\end{abstract}

Keywords: Aequitas; Equity; Rome; Roman Law; Justice.

${ }^{32}$ Tradução nossa. No original: "Sul diritto di Roma, si edificò il diritto del mondo." 


\section{REREFÊNCIAS BIBLIOGRÁFICAS}

ANDO, Clifford. "Exemplum, analogy, and precedent in Roman law". In: LOWRIE, Michèle; LÜDEMANN, Susanne (Eds.). Exemplarity and singularity: Thinking through Particulars in Philosophy, Literature, and Law. Oxon; New York: Routledge, 2015.

ARANGIO-RUIZ, Vicente. Historia del Derecho Romano. Trad. Francisco de Pelsmaeker e Ivañez. 3. ed. Madrid: Reus, 1974.

1952.

Instituciones de Derecho Romano. Trad. José M. Caramés Ferro. Buenos Aires: Editorial Depalma,

ARISTÓTELES. Tratados de lógica (Órganon). Trad. Miguel Candel Sanmartín. v. II. Madrid: Gredos, 1995. v. II.

BAUMAN, Richard A. Women and Politics in Ancient Rome. London: Routledge, 1994.

BOBBIO, Norberto. L'analogia nella logica del diritto. Torino: Istituto Giuridico dela R. Università, 1938.

BONFANTE, Pietro. A essência da bona fides e sua relação com a teoria do erro. Trad. Vítor Pimentel Pereira.

Revista Quaestio Iuris, v. 4, n. 1, p. 189-218, 2011.

Diritto Romano. Firenze: Casa Editrice Libraria Fratelli Cammelli, 1900.

1944 , v. I.

Historia del Derecho Romano. Trad. José Santa Cruz Teijeiro. Madrid: Revista de Derecho Privado,

Istituzioni di Diritto Romano. 10. ed. Torino: G. Giappichelli, 1951.

BRETONE, Mario. História do Direito Romano. Trad. Isabel Teresa Santos e Hossein Seddighzadeh Shooja. Lisboa: Estampa, 1998.

CAPE JR, Robert W. "Cicero and the Development of Prudential Practice at Rome". In: HARIMAN, Robert (ed.). Prudence: classical virtue, postmodern practice. University Park: The Pennsylvania State University Press, 2003.

CARMIGNANI, Maria Cristina. "A aequitas e a aplicação do direito em Roma". Revista da Faculdade de Direito da Universidade de São Paulo, São Paulo, v. 104, p. 115-129, jan./dez. 2009.

CARRÉ DE MALBERG, Raymond. Histoire de l'exception en droit romain e dans l'ancienne procédure française. Paris: Arthur Rousseau, 1887.

CHAMOUN, Ebert. Instituições de Direito Romano. Rio de Janeiro: Revista Forense, 1951.

CÍCERO. Cicero's Topica. Trad. Tobias Reinhardt. Oxford: Oxford University Press, 2003.

Da República. Trad. Amador Cisneiros. São Paulo: Abril Cultural, 1973. (Os Pensadores).

Dos deveres. Trad. Carlos Humberto Gomes. Lisboa: Edições 70, 2000.

Do sumo bem e do sumo mal. Trad. Carlos Ancêde Nougué. São Paulo: Martins Fontes, 2005.

La invención retórica. Trad. Salvador Núñez. Madrid: Gredos, 1997.

Las leyes. Trad. esp. Álvaro D'Ors. Madrid: Instituto de Estudios Políticos, 1953. 
Le orazioni. Torino: Unione Tipografico-Editrice Torinese, 1981.v. 1.

On the Commonwealth and On the Laws. Edited by James E. G. Zetzel. Cambridge: Cambridge University Press, 1999.

Opere retoriche. Torino: Unione Tipografico-Editrice Torinese, 1970. v. 1.

CORNIL, Georges. Ancien Droit Romain: le problème des origines. Bruxelles: Établissements Émile Bruylant; Paris: Librarie du Recueil Sirey, 1930.

CORRÊA, Alexandre Augusto de Castro. O estoicismo no Direito Romano. São Paulo, 1950.

CORREIA, Alexandre; SCIASCIA, Gaetano. Manual de Direito Romano. São Paulo: Saraiva, 1951, v. II.

CUQ Édouard. Manuel des institutiones juridiques des romains. 2. ed. Paris: Plon, 1928.

DEMANGEAT, M. Charles. Cours élémentaire de Droit Romain. 3. ed. Paris: A. Marescq Ainé, 1876, t. I.

DUCOS, Michèle. Roma e o Direito. Trad. Silvia Sarzana e Mário Pugliesi Netto. São Paulo: Madras, 2007.

FALCÓN Y TELLA, María José. Equidad, Derecho y Justicia. Madrid: Editorial Universitaria Ramón Areces, 2005.

FARIA, Ernesto. Dicionário escolar latino-português. 3. ed. Rio de Janeiro: Ministério da Educação e Cultura, 1962.

GIFFARD, A.-E. Précis de Droit Romain. 4. ed. Paris: Dalloz, 1951.t. I.

GIRARD, Paul Frédéric. Manuel élémentaire de droit romain. 4. ed. Paris: Arthur Rousseau, 1906.

JUSTINIANO. Cuerpo del Derecho Civil Romano: Digesto. Trad. D. Ildefonso L. García Del Corral. Barcelona: Kriegel, Hermann y Osenbrüggen, 1892.t. II.

Cuerpo del Derecho Civil Romano: Digesto. Trad. D. Ildefonso L. García Del Corral. Barcelona: Kriegel, Hermann y Osenbrüggen, 1897.t. III.

Cuerpo del Derecho Civil Romano: Instituta.-Digesto. Trad. D. Ildefonso L. García Del Corral. Barcelona: Kriegel, Hermann y Osenbrüggen, 1889. t. I.

KRUEGER, Paul. Histoire des sources du Droit Romain. Trad. M. Brissaud. Paris: Thorin \& Fils, 1894.

LAGES, Affonso. Aspectos do direito honorário. Belo Horizonte: Imprensa Oficial, 1949.

MARTINS-COSTA, Judith. A Boa-Fé no Direito Privado: critérios para a sua aplicação. São Paulo: Marcial Pons, 2015.

MASTINO, Isabella. "Utilitas valuit propter honestatem": Cicerone e il principio giuridico dell'utilitas. Diritto@Storia, Sassari, n. 11, 2013. Disponível em http://www.dirittoestoria.it/11/D\&Innovazione/MastinoCicerone-Principio-giuridico-utilitas.htm. Acesso em 26 jul. 2016.

MATOS, Andityas Soares de Moura Costa. O estoicismo imperial como momento da ideia de justiça: 
universalismo, liberdade e igualdade no discurso da Stoá em Roma. 2009. 416f. Tese (Doutorado em Filosofia do Direito) - Faculdade de Direito, Universidade Federal de Minas Gerais, Belo Horizonte, 2009.

MOMMSEN, Theodor. History of Rome. Trad. William P. Dickson. London: Richard Bentley, 1862. v. I.

MONCADA, Luis Cabral de. Elementos de História do Direito Romano. Coimbra: Coimbra Editora, 1923.

MOREIRA ALVES, José Carlos. Direito Romano. 13. ed. Rio de Janeiro: Forense, 2000. v. 1.

NÓBREGA, Vandick Londres da. História e sistema do direito privado romano. 3. ed. Rio de Janeiro; São Paulo: Freitas Bastos, 1962.

PEIXOTO, José Carlos de Matos. Curso de Direito Romano. 4. ed. Rio de Janeiro: Renovar, 1997.

PEROZZI, Silvio. Istituzioni di Diritto Romano. 2. ed. Roma: Athenaeum, 1928. v. I.

PETIT, Eugène. Traité élémentaire de Droit Romain. 4. ed. Paris: Arthur Rousseau, 1903.

PINTO COELHO, Saulo de Oliveira. Introdução ao Direito Romano: constituição, categorização e concreção do Direito em Roma. Belo Horizonte: Atualizar, 2009.

PLATÃO. República. Trad. Maria Helena da Rocha Pereira. 9. ed. Lisboa: Calouste Gulbenkian, 2001.

Diálogos. O banquete. Fédon. Sofista. Político. Trad. José Cavalcante de Souza, Jorge Paleikat e João Cruz Costa. São Paulo: Abril Cultural, 1972.

POHLENZ, Max. La Stoa: storia di um movimento spirituale. Trad. Ottone de Gregorio. Firenze: La Nuova Italia, 1967, v. 1.

RAMOS, Juan Arias. Derecho Romano. 4. ed. Madrid: Editorial Revista de Derecho Privado, s/d.

RODRÍGUEZ-GARCÍA, Fausto E. “La analogia en el derecho”. In: RODRÍGUEZ-GARCÍA, Fausto E. (Coord.) Estudios en honor del doctor Luis Recaséns Siches. México, D. F.: Universidad Nacional Autónoma de México, 1987, v. II.

SALAZAR REVUELTA, María. "Formación en el derecho romano y en la tradición romanística del principio de la buena fe y su protección en el derecho comunitario europeo". Revista internacional de derecho romano [on line], p. 111-187, abr. 2015.

SALGADO, Joaquim Carlos. "A experiência da consciência jurídica em Roma”. Revista do Tribunal de Contas do Estado de Minas Gerais, Belo Horizonte, ano XIX, n. 1, 2001.

A ideia de justiça no mundo contemporâneo: fundamentação e aplicação do direito como maximum ético. Belo Horizonte: Del Rey, 2006.

SANTOS, Igor Moraes. A res publica entre a ideia e a história: filosofia, eloquência e tradição no pensamento político-jurídico de Marco Túlio Cícero. 496f. Dissertação (Mestrado em Direito). - Faculdade de Direito, Universidade Federal de Minas Gerais, Belo Horizonte, 2018. 
SCATOLIN, Adriano. A invenção no Do orador de Cícero: um estudo à luz de Ad Familiares I, 9, 23. 2009. 308f. Tese (Doutorado em Letras Clássicas). - Faculdade de Filosofia, Letras e Ciências Humanas, Universidade de São Paulo, São Paulo, 2009.

SCHULZ, Fritz. History of Roman Legal Science. Oxford: Clarendon Press, 1946.

Principles of Roman Law. Trad. Marguerite Wolff. Oxford: Clarendon Press, 1936.

SCIALOJA, Vittorio. "Del diritto positivo e dell'equità". Annali della Facoltà Giuridica dell'Università di Camerino, Camerino, n. 1, p. 179-205, 2012.

TITO LÍVIO. History of Rome. Trad. B. O. Foster. London; New York: William Heinemann; G. P. Putnam's Sons, 1926, v. 4. (The Loeb Classical Library).

TUCCI, José Rogério Cruz e; AZEVEDO, Luiz Carlos. Lições de história do processo civil romano. 2. ed. São Paulo: Revista dos Tribunais, 2013.

VILLEY, Michel. Le Droit Romain. Paris: Presses Universitaires de France, 1949.

Trabalho enviado em 27 de fevereiro de 2018.

Aceito em 27 de março de 2018. 